OPEN ACCESS

Edited by:

Susana Novella,

University of Valencia, Spain

Reviewed by:

Peter J. Toth,

University of Pécs, Hungary

Ana B. Paes,

INCLIVA Biomedical Research

Institute, Spain

*Correspondence:

Rita C. Tostes

rtostes@usp.br

Eliana H. Akamine

eliakamine@usp.br

Specialty section:

This article was submitted to

Molecular Mechanisms of Aging,

a section of the journal

Frontiers in Aging

Received: 19 June 2021

Accepted: 25 August 2021

Published: 08 September 2021

Citation:

Barros PR, Costa TJ, Akamine EH and Tostes RC (2021) Vascular Aging in

Rodent Models: Contrasting

Mechanisms Driving the Female and

Male Vascular Senescence.

Front. Aging 2:727604.

doi: 10.3389/fragi.2021.727604

\section{Vascular Aging in Rodent Models: Contrasting Mechanisms Driving the Female and Male Vascular Senescence}

\author{
Paula R. Barros ${ }^{1}$, Tiago J. Costa ${ }^{1}$, Eliana H. Akamine ${ }^{2 *}$ and Rita C. Tostes ${ }^{1 *}$ \\ ${ }^{1}$ Department of Pharmacology, Ribeirão Preto Medical School, University of São Paulo, Ribeirão Preto, Brazil, ${ }^{2}$ Department of \\ Pharmacology, Institute of Biomedical Science, University of São Paulo, São Paulo, Brazil
}

Increasing scientific interest has been directed to sex as a biological and decisive factor on several diseases. Several different mechanisms orchestrate vascular function, as well as vascular dysfunction in cardiovascular and metabolic diseases in males and females. Certain vascular sex differences are present throughout life, while others are more evident before the menopause, suggesting two important and correlated drivers: genetic and hormonal factors. With the increasing life expectancy and aging population, studies on aging-related diseases and aging-related physiological changes have steeply grown and, with them, the use of aging animal models. Mouse and rat models of aging, the most studied laboratory animals in aging research, exhibit sex differences in many systems and physiological functions, as well as sex differences in the aging process and agingassociated cardiovascular changes. In the present review, we introduce the most common aging and senescence-accelerated animal models and emphasize that sex is a biological variable that should be considered in aging studies. Sex differences in the cardiovascular system, with a focus on sex differences in aging-associated vascular alterations (endothelial dysfunction, remodeling and oxidative and inflammatory processes) in these animal models are reviewed and discussed.

Keywords: vascular aging, aging, vascular dysfunction, sex difference, vascular senescence

\section{INTRODUCTION}

Studies involving sex differences in cardiovascular biology have increased in recent years. Many mechanisms, that differ in males and females, orchestrate vascular function and vascular abnormalities in cardiovascular and metabolic diseases. Women are hemodynamically younger than men of the same age, and cardiovascular disease is more prevalent in men than women (World Health Organization, 2015). However, after menopause, many (but not all) sex differences in cardiovascular disease are abrogated, suggesting two significant and correlated drivers: genetic and hormonal factors (World Health Organization, 2015).

With the increasing life expectancy and aging population, studies on aging-related physiological changes and aging-related diseases have steeply grown, and, with them, the use of aging animal models. Mouse and rat models of aging, the most studied laboratory animals in aging research, exhibit sex differences in many systems and physiological functions, as well as sex differences in the aging process and aging-associated cardiovascular changes. As expected, aging and senescenceaccelerated animal models used to study sex differences present limitations. 


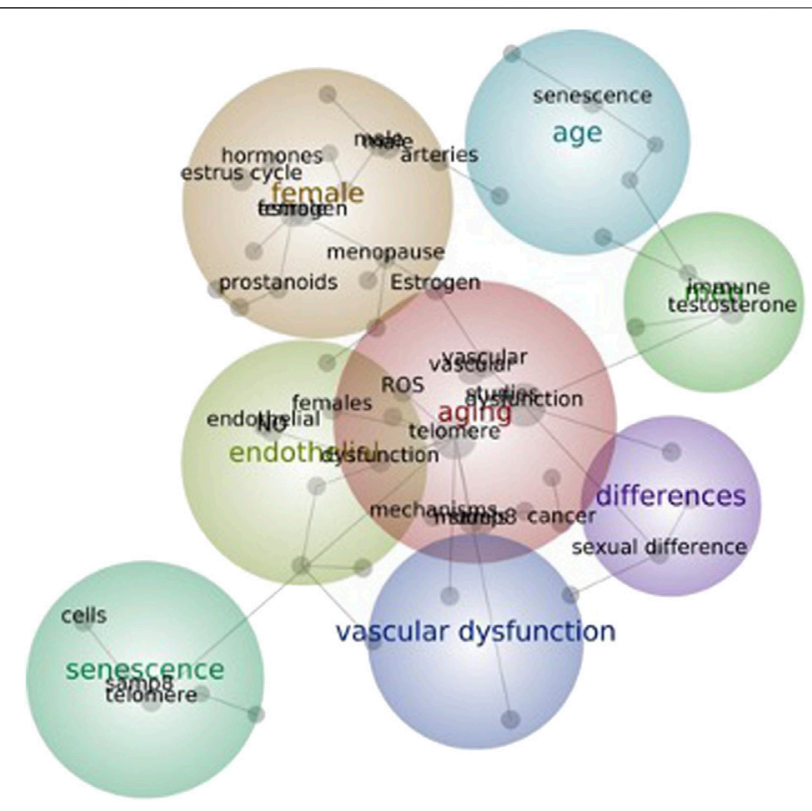

FIGURE 1 | Connections within the vascular system, aging and sex themes. The Concept map was elaborated using the Leximancer algorithm, the original manuscripts and the keywords: aging, senescence, female, male, endothelium and vascular dysfunction. The lines between the concepts (grey circles) show typical pathways linking the concept terms. The size of the grey circles indicates the overall relative frequency of concepts.

Therefore, the main characteristics of aging animal models, considering sex as a biological variable are considered in the present review. Sex differences in the cardiovascular system, with a focus on sex differences in aging-associated vascular alterations (endothelial dysfunction, remodeling and oxidative and inflammatory processes) that occur in these animal models are described and discussed. Figure 1, elaborated with the Leximancer algorithm Concept, depicts a map with three primary themes (vascular dysfunction, aging and sex differences). The map reinforces the complexity and interrelationships between these variables, as indicated by the interactions between the interconnected subthemes.

\section{The Aging Process}

Aging is an irreversible process yet little understood in human biology. Biological aging is an intrinsic, progressive, and generalized deterioration of biological homeostasis that occurs over time (Kovacic et al., 2011). It's a complex process that involves several biological changes, in addition to the cellular senescence described by Hayflick and Moorhead (1961), as will be discussed.

López-Otín et al. (2013) identified and categorized the cellular and molecular characteristics of aging, proposing a total of nine markers that, together, can determine the aging phenotype: 1) genomic instability, 2) shortening of telomeres, 3) epigenetic changes, 4) loss of proteostasis, 5) unregulated detection of nutrients, 6) mitochondrial dysfunction, 7) cell senescence, 8) stem cell exhaustion, and 9) altered intercellular communication. These processes are interrelated, suggesting that aging is not the result of the malfunction of a single parameter, but rather a combination of different molecular changes. With the progression of aging, the changes in these many processes coincide with the emergence of age-related diseases that alter the body homeostasis and reduce the quality of life (Da Costa et al., 2016; Lees et al., 2016).

In 2050, 1 in 6 people in the world will be over the age of 65 , up from 1 in 11 in 2019 (United Nations, 2019). Older people account for more than one fifth of the population in 17 countries and in 2,100 this will be the case for 155 countries, covering $61 \%$ of the world's population (United Nations, 2019). These numbers represent a public health problem, since aging remains the strongest risk factor for cardiovascular disease (CVD) (World Health Organization, 2015), even after correction for classic cardiovascular risk factors, such as smoking, physical inactivity, arterial hypertension, diabetes, and obesity (Lakatta and Levy, 2003; Erusalimsky, 2009; Erusalimsky and Skene, 2009).

\section{Sex Differences in Aging}

Physiological mechanisms that control vascular function are different in men and women. Mechanisms involved in diseases-associated vascular dysfunction also seem to follow a different pattern of development in males and females. In aging, these sex differences are already seen in life expectancy, where women currently outlive men by 4.8 years (United Nations, 2019).

Sex hormones are responsible for the most marked endocrine changes with aging (Horstman et al., 2012). In men, aging-related changes, including sexual dysfunction, decreased muscle strength, muscle and joint pain, insomnia, and physical exhaustion (Heinemann, 2005), usually appear as early as in middle age, 40- to 59-year-old men, with reduced testosterone levels since the age of 35-40 (Feldman et al., 2002). In women, aging is associated with the postmenopausal period, linked to a decrease in the natural sex hormones, estrogen and progesterone, and increased follicle-stimulating hormone (FSH) levels (El Khoudary et al., 2020). Although the risk for CVD increases with the aging process in both sexes, it is more severe in postmenopausal women (El Khoudary et al., 2020). The mechanisms that determine the aging condition in men and women are targeted by a growing number of studies (Nakamura and Miyao, 2008; Austad, 2019).

The aging of the population will cause an increasing burden to the health systems, implying profound changes in public health policies. Therefore, it is very important to improve our knowledge on the changes that occur in biological systems during men and women aging, since this might reveal potential therapeutic targets to reduce aging-related cardiovascular dysfunction, and prevent lethal or debilitating cardiovascular events.

\section{Cellular Senescence}

Hayflick and Moorhead (1961) introduced the term "senescence" to describe the phenomenon of irreversible growth blockade of human diploid cells in culture after extensive series passages, later known as "replicative senescence". At some point, cells arrive at a steady state, called the Hayflick limit, and they become senescent 


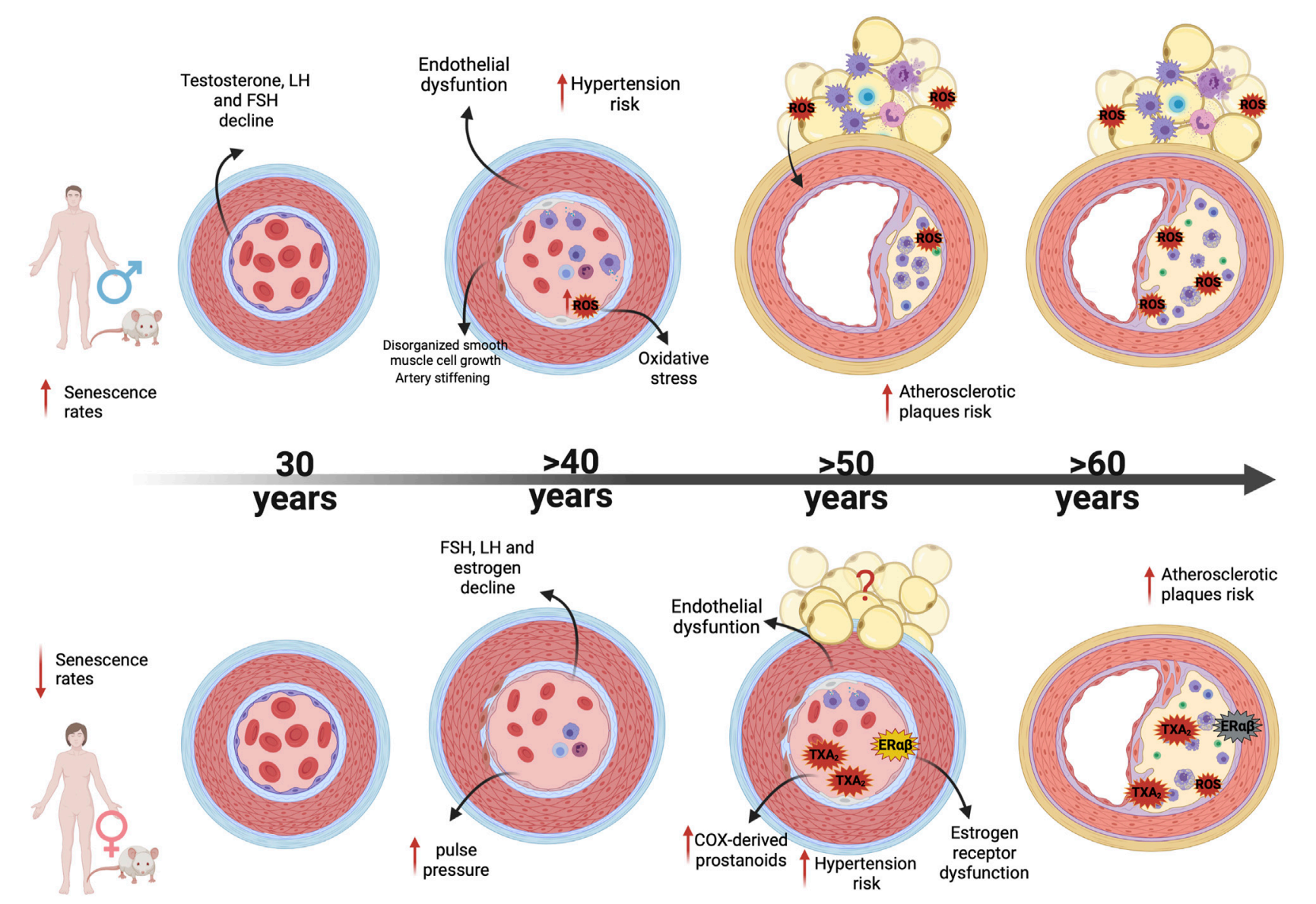

FIGURE 2 | Mechanisms associated with sex differences in vascular aging. Figure illustrates vascular and PVAT age-associated alterations observed in male and female; from differences in age onset of vascular dysfunction (males show higher senescence rates than females) to different mechanisms of endothelial dysfunction, vascular remodeling and oxidative and inflammatory processes as men and women age increases. Abbreviations: LH, Luteinizing Hormone; FSH, Follicle-stimulating hormone; TXA2, Thromboxane; ERa, Estrogen receptor alpha; ER $\beta$, Estrogen receptor; ROS, Reactive Oxygen Species.

(Hayflick and Moorhead, 1961). Long after the Hayflick and Moorhead discovery, and considering Olovnikov's endreplication telomere loss problem (Olovnikov, 1971; Olovnikov, 1973), the molecular mechanism underlying the Hayflick limit was explained: the shortening of telomeres. Telomeres are repeated sequences, rich in T-G bases ( $\mathrm{Xu}$ et al., 2013) sequenced as 5'TTAGGG3' in vertebrates (Hemann and Greider, 1999) found at chromosome ends, which shorten with each cell duplication. The telomeres shortening or the loss of telomere t-loop structure (Olovnikov, 1973; Levy et al., 1992; Greider, 2000) is sensed by the cell as a DNA damage, and cell signaling is activated within to stop the cell cycle and to increase a proinflammatory secretory phenotype (Van Deursen, 2014), supporting the original hypothesis of Hayflick and Moorhead, in which senescence protects against the unrestricted growth of damaged cells. Subsequently, it was found that not only the cells of an elderly individual become senescent, but that all differentiated cells, such as fibroblasts, have a limited division potential before undergoing the so-called "replicative senescence".

Cellular senescence can be seen as an important physiologic mechanism of protection. Unlike a static endpoint, senescence represents a very dynamic cellular process that can happen in different states of the cell to protect against different cell stressors, as seen in autophagy and cancer (Slobodnyuk et al., 2019), embryonic development (Rajagopalan and Long, 2012; MuñozEspín et al., 2013; Storer et al., 2013), tissue repair (Krizhanovsky et al., 2008; Jun and Lau, 2010), aging and age-related disorders (Baker et al., 2008). This leads to a couple of questions: how can senescent cells be present in such antagonic situations as embryonic development and aging? Do they have different roles? Are there different types of senescence in cells? A recent review Van Deursen (2014) discussed that senescent cells can be divided into two types: acute and chronic senescent cells, based on the kinetics of senescence induction and functionality.

Acute senescent cells are part of a tightly orchestrated biological processes (that is, wound healing, tissue repair, embryonic development) induced through cell-extrinsic stimuli that target a specific population of cells in the tissue. This process aims to halt expansion of certain cells or to produce a senescenceassociated secretory phenotype (SASP) with well-defined paracrine functions. For example, in wound closure or tissue development, myofibroblasts suddenly undergo senescence 
(acute senescence) to limit excessive fibrosis at the site of injury (Jun and Lau, 2010) such as in liver damage (Krizhanovsky et al., 2008). Acute senescent cells self-organize by releasing SASPs to attract immune cells in charge for their resolution/elimination in the tissue (Van Deursen, 2014).

Chronic senescent cells arise after periods of progressive cellular stress and chronic senescence does not seem to target specific cell types. Possibly due to age-related immunodeficiency or decreased production of pro-inflammatory SASPs, as exemplified by melanocytic nevi (Benz et al., 1991), immune cells may inefficiently eliminate chronic senescent cells, allowing continuation of multi-step senescence. In addition, in agingrelated senescence, the switch from temporal to persistent cellcycle arrest appears unscheduled, probably involving the combined effects of distinct senescence-inducing stressors acting simultaneously on a cell (Van Deursen, 2014).

But can acute and chronic senescent cells permeate between those states? Senescence induced during cancer therapy may initially be acute and later chronic in nature (Roberson et al., 2005; Gewirtz et al., 2008), but the other way around is still controversial in the literature. It is possible that senescence may initially have arisen as a developmental or wound healing mechanism that has only recently in evolutionary time adapted as a tumor suppressor mechanism with aging as a side-effect (Campisi, 1997). Cultured cells usually reach senescence within several weeks after exposure to senescenceinducing stressors but remain viable for months thereafter (De Cecco et al., 2013). Senescent cells continue to evolve even after extended periods of culture, thereby progressing to a stage that has been termed "deep" or "late" senescence.

The exact point where senescent cells fail to manifest their beneficial effects through the SASP and promote a tissue-specific disease is still unknown. So, at what time would it be desirable to eliminate the senescent cells? This evidence implies that senescence and other cellular responses to stress might be related to life span and health span, not only the lack of them, but also an overstated response, and might provoke disease. Not all cells become senescent at the same time, but the senescent phenotype can be transmitted to neighboring cells (Hoare and Narita, 2013). So, what if the senescent cells that perform the beneficial effects are not the first ones that became senescent? It might be necessary the accumulation of a certain number of senescent cells to carry out these effects; and what if those cells were eliminated before they could induce senescence in their neighbor cells? These questions still need to be answered in aging research.

\section{Sex Differences in Senescence}

Males show higher senescence rates than females and this sex difference is largely attributable to sex-specific downstream effects of the intensity of intra-sexual competition experienced during early adulthood (Promislow, 1992; Maklakov and Lummaa, 2013; Chen and Maklakov, 2014). However, one of the criticisms is that these studies are carried out in species with low extrinsic mortality and the mechanisms that generate such differences remain poorly understood (Beirne et al., 2015).

Since senescence has been related to telomere shortening, the influence of sex on telomere suggests that a sex bias in telomere maintenance does exist, since female rats might have greater telomerase activity (Leri et al., 2000). In fact, estrogen activates a promoter of telomerase (Kyo et al., 1999) and indirectly also affects DNA repair through the p53 pathway. An estrogenresponsive element (ERE) is present in telomerase reverse transcriptase (hTERT) indicating that estrogen might stimulate telomerase to add telomere repeats to the ends of chromosomes (Nordfjäll et al., 2005). Telomeres are particularly sensitive to oxidative stress (Van Der Harst et al., 2007) and, in physiological conditions, the levels of reactive oxygen species (ROS) are lower in the vascular system of premenopausal women than men (Ide et al., 2002; Kander et al., 2017). A meta-analysis study suggested that women have longer telomeres than men irrespective of cell type or age. It's important to mention that different techniques are used to measure telomeres length, such as real-time PCR, Flow-FISH, and Southern blotting. However, only Southern blotting showed significant differences in mean telomere length between the sexes (Gardner et al., 2014), while other studies showed that women does not always have longer telomeres (Hunt et al., 2008; Shiels et al., 2011).

Endothelial senescence has been more and more explored, especially because aging per se is a risk factor for endothelial dysfunction (Erusalimsky, 2009; Erusalimsky and Skene, 2009). In the vascular system the problem is that in vitro studies of cellular endothelial senescence have traditionally been performed using a single senescence-inducing stimulus in endothelial cells: mitogens (Kurz et al., 2003), inflammatory molecules (Breitschopf et al., 2001) or ROS (Kurz et al., 2004). However, in the context of organismal aging, individual cells experience multiple cellular pressures, including various kinds of genotoxic, proteotoxic and mitotic stresses (Hayflick and Moorhead, 1961; Siegel and Amon, 2012). Thus, to advance our understanding of these processes, one should examine how combinations of diverse senescencepromoting stressors impact the actions of the various downstream effector pathways and whether the characteristics of the resulting SASP vary in distinct cell types and under different senescence-inducing stressors (Coppé et al., 2008). The SASP produced by senescent cells might be a good parameter to explore the effects of several senescenceinducing stimuli in endothelial cells from males and females. There are several SASPs that depend on persistent DNA damage signaling (Rodier et al., 2009) and that is independent of DNA damage (Freund et al., 2011), implying the existence of DNA damage response-independent mechanisms (Kaplon et al., 2013; Muñoz-Espín et al., 2013; Storer et al., 2013).

\section{EXPERIMENTAL ANIMAL MODELS FOR AGING STUDIES}

\section{Models to Study Aging}

According to the National Institutes of Health (National Human Genome Research Institute), an animal model is a non-human species used in medical research because it can mimic aspects of a disease found in humans. Animal models are used to obtain information about a disease and its prevention, diagnosis, and 
TABLE 1 | Genetically-engineered mouse models regularly used in aging research and the age-distinguishing characteristic (hallmark) in males and females.

\begin{tabular}{|c|c|c|c|c|}
\hline Mouse model & Gene targeting & Human syndrome & Age hallmark & References \\
\hline Ercc1 $^{-/-}$ & Ercc1 knockout & XFE progeroid syndrome & Genomic instability & Weeda et al. (1997) \\
\hline $\operatorname{Ercc}^{-1 / \Delta 7}$ & Ercc1 hypomorphic & & Genomic instability & Dollé et al. (2011) \\
\hline $\mathrm{Ercc}^{2 \mathrm{R} 722 \mathrm{~W} / \mathrm{R} 722 \mathrm{~W}}, \mathrm{Xpd}^{\mathrm{TTD} / \mathrm{TT}}$ & Ercc2 knockin & Trichothiodystrophy & Genomic instability & de Boer et al. (2002) \\
\hline $\operatorname{Ercc}^{\mathrm{m} / \mathrm{m}}, \mathrm{Xpf}^{\mathrm{m} / \mathrm{m}}$ & Ercc4 knockout & Xeroderma pigmentosum group F & Genomic instability & Tian et al. (2004) \\
\hline $\operatorname{Ercc5}^{-1-}, \mathrm{Xpg}^{-/-}$ & Ercc5 knockout & $\begin{array}{l}\text { Xeroderma pigmentosum group } \\
\text { G/Cockayne syndrome }\end{array}$ & Genomic instability & Barnhoorn et al. (2014) \\
\hline Ercc6 $^{\mathrm{m} / \mathrm{m}} / \mathrm{Xpa}^{-/-}, \mathrm{Csb}^{\mathrm{m} / \mathrm{m}} / \mathrm{Xpa}^{-/-}$ & $\begin{array}{l}\text { Double Ercc6/Xpa } \\
\text { knockout }\end{array}$ & Cockayne syndrome & Genomic instability & van der Pluijm et al. (2007) \\
\hline $\operatorname{Xrcc5}^{-/-},{\mathrm{Ku} 80^{-/-} \text {or Ku86 }}^{-/-}$ & Xrcc5 knockout & & Genomic instability & Li et al. (2007) \\
\hline $\operatorname{Xrcc6}^{-/-}, \mathrm{Ku}_{70}^{-/-}$ & Xrcc6 knockout & & Genomic instability & Espejel et al. (2004) \\
\hline Prkdc $^{-/-}, \operatorname{Xrcc}^{-/-}$or DNA-PKcs ${ }^{-/-}$ & Prkdc knockout & & Genomic instability & Li et al. (2007) \\
\hline $\mathrm{Wrn}^{-/-} / \mathrm{Terc}^{-/-}$ & $\begin{array}{l}\text { Double Wrn/Terc } \\
\text { knockout }\end{array}$ & Werner syndrome & Genomic instability & Espejel et al. (2004) \\
\hline Bub1b ${ }^{\mathrm{H} / \mathrm{H}}, \mathrm{BubR} 1^{\mathrm{H} / \mathrm{H}}$ & Bub1b hypomorphic & & Genomic instability & Chang et al. (2004) \\
\hline Bub1b+/GTAA , BubR1 1/GTTA & Bub1b knockin & $\begin{array}{l}\text { Mosaic variegated aneuploidy } \\
\text { syndrome }\end{array}$ & Genomic instability & Baker et al. (2004) \\
\hline $\mathrm{Bub3}^{+/-} / \mathrm{Rae}^{+/-}$ & $\begin{array}{l}\text { Double Bub3/Rae1 } \\
\text { haploinsufficient }\end{array}$ & & Genomic instability & Wijshake et al. (2012) \\
\hline SprtnH/H & Sprtn hypomorphic & Ruijs-Aalfs syndrome & Genomic instability & Baker et al. (2006) \\
\hline 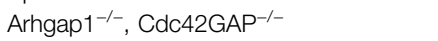 & Arhgap1 knockout & & Genomic instability & Maskey et al. (2014) \\
\hline$A t r$ S/S & Atr hypomorphic & Seckel syndrome & Genomic instability & Wang et al. (2007) \\
\hline Atrflox/-$:$ Cre-ERT2 $^{+}$ & Atr inducible knockout & Seckel syndrome & Genomic instability & Murga et al. (2009) \\
\hline Polg ${ }^{\mathrm{D} 257 \mathrm{~A} D 257 \mathrm{~A}}$, mtDNA mutator mouse & Polg knockin & & Genomic instability & Ruzankina et al. (2007) \\
\hline $\begin{array}{l}\mathrm{Lmna}^{\mathrm{G} 609 G / G 609 G}, \mathrm{LAKI} \text { mouse, } \\
\mathrm{Lmna}^{\mathrm{L} 530 \mathrm{P} / \mathrm{L} 530 \mathrm{P}}, \mathrm{Lmna}^{\mathrm{HG} /+} \\
\mathrm{Lmna}^{\mathrm{H} 222 \mathrm{P} / \mathrm{H} 222 \mathrm{P}}\end{array}$ & Lmna knockin & $\begin{array}{l}\text { Hutchinson-Gilford progeria } \\
\text { syndrome }\end{array}$ & Genomic instability & $\begin{array}{l}\text { Osorio et al. (2011); Trifunovic et al. } \\
\text { (2004); Mounkes et al. (2003) }\end{array}$ \\
\hline Zmpste24 $4^{-/-}$ & Zmpste24 knockout & $\begin{array}{l}\text { Hutchinson-Gilford progeria } \\
\text { syndrome }\end{array}$ & Genomic instability & $\begin{array}{l}\text { Bergo et al. (2002); Pendás et al. } \\
(2002)\end{array}$ \\
\hline Terc $^{-/-}$ & Terc knockout & Dyskeratosis congenita & Telomere attrition & Rudolph et al. (1999) \\
\hline Tert $^{\mathrm{ER}}$ & Tert knockin & Dyskeratosis congenita & Telomere attrition & Jaskelioff et al. (2011) \\
\hline Tert $^{-/-}$ & Tert knockout & Dyskeratosis congenita & Telomere attrition & Bär et al. (2016) \\
\hline Sirt6 $^{-/-}$and Sirt $1^{-/-}$ & Sirt1-6 knockout & & Epigenetic alterations & $\begin{array}{l}\text { Mostoslavsky et al. (2006); } \\
\text { Mercken et al. (2014) }\end{array}$ \\
\hline $\mathrm{Bmi1}^{-/-}$ & Bmi1 knockout & & Epigenetic alterations & van der Lugt et al. (1994) \\
\hline Sod $1^{-/-}$and Sod $2^{-/-}$ & Sod1-2 knockout & & Oxidative stress & Li et al. (1995); Elchuri et al. (2005) \\
\hline $\mathrm{Msr}^{-/-}$ & MsrA gene knockout & & Oxidative stress & Moskovitz et al. (2001) \\
\hline $\operatorname{Prd} \times 1^{-/-}$ & Prdx1 gene knockout & & Oxidative stress & Neumann et al. (2003) \\
\hline $\mathrm{Kl}{ }^{\mathrm{kl} / \mathrm{kl}}, \mathrm{Klotho} \mathrm{ol}^{\mathrm{kl} / \mathrm{kl}}$ & KI knockout & & $\begin{array}{l}\text { Altered intercellular } \\
\text { communication }\end{array}$ & Kuro-o et al. (1997) \\
\hline bGH-Tg, GH-transgenic mice & $\begin{array}{l}\text { Overexpression of } \\
\text { Growth Hormone }\end{array}$ & & $\begin{array}{l}\text { Somatotropic }(\mathrm{GH} / \\
\text { IGF-1) axis }\end{array}$ & Casellas and Medrano, (2008) \\
\hline $\mathrm{Nfkb} 1^{-/-}$ & Nfkb1 knockout & & $\begin{array}{l}\text { Altered intercellular } \\
\text { communication }\end{array}$ & Bernal et al. (2014) \\
\hline$\| 10^{\mathrm{tm} / \mathrm{tm}}$, Frail mouse & \|10 knockout & & $\begin{array}{l}\text { Altered intercellular } \\
\text { communication }\end{array}$ & $\begin{array}{l}\text { Kühn et al. (1993); Walston et al. } \\
\text { (2008) }\end{array}$ \\
\hline
\end{tabular}

HGPS, Hutchinson-Gilford progeria syndrome; ERCC1, excision repair cross complementing 1; IL-10, interleukin-10; Lmna, Lamin A; PolG, Polymerase $\gamma$; Terc, Telomerase RNA component; Wfs, Wolfram syndrome; Wrn, Werner syndrome ATP-dependent helicase; WS, Werner syndrome; XPD, xeroderma pigmentosum, complementation group F; Zmpste24, zinc metalloproteinase Ste24; CHIP, carboxyl terminus of Hsp70-interacting protein; MsrA, Methionine sulfoxide reductase; Prdx1, peroxiredoxin 1.

treatment. By using animals, researchers can carry out experiments that would be impractical or ethically prohibited with humans (sic) (National Human Genome Research Institute, 2021).

In that context, a few common model organisms are studied in aging research, such as single-cell yeast, Saccharomyces cerevisiae; the nematode Caenorhabditis elegans; the fruit fly Drosophila melanogaster, the laboratory mouse (Mus musculus) and rat (Rattus norvegicus). These species span a considerable distance in animal evolution, but shared features of these evolutionary divergent animals strongly indicate the presence of some conserved processes in aging (Mitchell et al., 2015).
However, there is still considerable debate concerning the extent of generality of ageing mechanisms in experimental animal models.

For several years, the use of invertebrate animal models such as Caenorhabditis elegans or Drosophila melanogaster, has led aging research by providing the first insights into those molecular pathways that are determinant in the aging process and for lifespan extension. However, for vascular aging studies, mouse models - in comparison with other mammals - are more complex, faster, and cheaper tools for lab research. Specifically, inbred aged mice models, such as the C57BL/6J mice, are commonly used in ageing vascular studies (Flurkey et al., 2007). 
TABLE 2 | Non genetically-modified mouse models regularly used in aging research and their relative ages of study in males and females.

\begin{tabular}{|c|c|c|c|c|c|c|}
\hline $\begin{array}{l}\text { Animal } \\
\text { models }\end{array}$ & $\begin{array}{l}\text { Maturation } \\
\text { (puberty) }\end{array}$ & $\begin{array}{c}\text { Young } \\
\text { (sexual } \\
\text { maturity) }\end{array}$ & $\begin{array}{c}\text { Middle-aged } \\
\text { (fall } \\
\text { of reproductive } \\
\text { functions) }\end{array}$ & Aged & $\begin{array}{l}\text { Life-span } \\
\text { (average) }\end{array}$ & References \\
\hline C57BL6 & \pm 28 days & $3-6$ months & 10-15 months & 18-24 months & 2 years & $\begin{array}{l}\text { Dutta and Sengupta, (2016); Yuan et al. } \\
\text { (2009) }\end{array}$ \\
\hline Wistar rat & \pm 28 days & 5-6 months & $\geq 18$ months & $\geq 24$ months & 3 years & Sengupta, (2013) \\
\hline $\begin{array}{l}\text { Fischer } 344 \\
\text { rats }\end{array}$ & \pm 28 days & 4-6 months & z18 months & $\geq 24$ months & 1.75 years & Chesky and Rockstein, (1976) \\
\hline SAMP8 & \pm 28 days & 2-3 months & $\geq 6$ months & $\geq 8$ months & 12.1 months & Takeda et al. (1981); Takeda, (1999) \\
\hline SAMR1 & \pm 28 days & 2-3 months & $\geq 8$ months & $\geq 10-15$ months & 18.9 months & Takeda et al. (1981); Takeda, (1999) \\
\hline CD1 mice & \pm 22 days & 3 months & $\geq 8$ months & $\geq 12-18$ months & 2 years & $\begin{array}{l}\text { Eveleigh et al. (1983); Russell and Green, } \\
\text { (2007) }\end{array}$ \\
\hline
\end{tabular}

\section{Rodent Models to Study Natural Aging}

As shown in a large cohort study with C57BL/6J mice (150 males and 150 females), the maturational rate of mice does not linearly correlate with humans. It occurs 150 times faster during the first month of life and 45 times faster over the next 5 months, during which mice pass through their mature adult stage. Mature adult mice, age from 3-6 months, are often used as the reference group (control) in aging studies, since this group is past development but not yet affected by aging outcomes. Although sexual maturity is reached around 35 days, rapid growth continues until about 3 months, with the life phase equivalent for humans ranging from 20-30 years (Flurkey et al., 2007). Middle-aged groups help determine if an agerelated change is progressive or is first expressed only in old animals. Mice should be at least 10 months-old and up to 15 months-old for inclusion in a middle age group. This phase correlates to humans that are 38-47 years-old. Mice at age 18-24 months correlate with humans in their 56-69 years. This age range meets the definition of "old," which is the presence of changes in almost all biomarkers of senescence. It is important to carefully choose the age cohorts such that animals used are neither too young nor too old. Animals that are nearing the end of their lives may already be riddled with ageassociated diseases, whereas those that are too young may still be undergoing the complex process of development and maturation (Mitchell et al., 2015).

Regardless of age, animal models should be healthy, pathogenand disease-free, and have no signs of tumors or lesions (Storer, 1966). The use of necropsy data, the dangers of pooling samples from different individuals, planning ahead for loss of aged mice to death and disease, the use of cost-adjusted power calculations, and the dangers of inferring causal associations from correlated age effects are important issues to be considered in aging research (Miller and Nadon, 2000).

Another important issue is that aging studies should be undertaken in both genders, for differences in genotype may be evident. For example, old male inbred CBA/J mice have a stronger likelihood of developing hepatocellular tumors than females (Nadon, 2006). Similarly, quantitative trait locus mapping of Drosophila genes has identified gender specific loci that differentially alter longevity (NuzhdinMackay and Mackay, 1994).
In terms of female vascular aging, a study in a model that also presents the menstrual phase of women would be ideal, but few species experience menstruation and this type of research is oftentimes ethically difficult and costly to perform. Although rats do not experience menses, they do experience estrus cycling and ovarian aging. Reproductive maturity of rodents is reached at 3-5 months, when there is an estrous cycle that lasts four to 5 days. Similarly, as women age, there is a progressive gradual decline in estrogen levels caused by changes in the hypothalamic-pituitary control of gonadotropin secretion and gonadal stimulation of estrogen (Yuan et al., 2005). Aged female rats and mice exhibit periods of persistent estrous cycle, consisting of elevated and constant levels of estradiol, low levels of progesterone, and lack of luteinizing hormone ( $\mathrm{LH}$ ), in addition to ovulation ( $\mathrm{Lu}$ et al., 1979; Simpkins et al., 1979; Yuan et al., 2005). Ovarian function declines between 3 and 6 months in the senescence-accelerated mouse prone 8 (SAMP8) model (NuzhdinMackay and Mackay, 1994) and at 10-12 months in Long Evans rats (Lu et al., 1979). Therefore, reproductive maturity depends on the rodent strain and is characterized by low levels of estradiol and progesterone, with little or no developing follicles and increased prolactin secretion (Advis et al., 1978; Lu et al., 1979; Simpkins et al., 1979).

\section{Senescence-Accelerated Mouse Models Genetically-Engineered Mouse Models}

The disadvantages of working with vascular aging in animals include 1) the long waiting time for the animal to grow old, 2) the long duration of the studies and 3) the different ages at which the studies are performed (Folkow and Svanborg, 1993; Küng and Lüscher, 1995; Zhou and Frohlich, 2003; Zieman et al., 2001). The main reason is undoubtedly the financial burden: aged mice must be either purchased (e.g., \$106 to grow a mouse for 2 years) or "matured" from a young age to 18-24 months, also expensive and time-consuming (Miller and Nadon, 2000).

Mice with accelerated vascular aging provide an alternative that saves time and energy. Mice with progeroid syndromes [well described in Liao and Kennedy (2014)] are widely used in aging research. These mice are termed progeroid, which means resembling premature aging, which in some cases involve mutations in the same genes that have been linked to human progeria syndromes (Burtner and Kennedy, 2010; Cox and 
Faragher, 2007; Kudlow et al., 2007). Most progeroid syndrome animal models are developed with a single gene deletion that leads to a strong phenotypic overlap with normal aging lesions (Table 1), well discussed by two reviews (Mitchell et al., 2015; Kõks et al., 2016).

Although transgenic mice have been proposed as an useful approach to study aging (Musarò and Rosenthal, 1999; Warner and Sierra, 2003), this multifactorial phenomenon will hardly be simulated by monogenic approaches. It also remains highly debatable to what extent the molecular events leading to progeria overlap with those driving normal aging (Hasty and Vijg, 2004; Kipling et al., 2004; Miller, 2004). Biogerontologists are increasingly realizing that "single molecule, single target" approaches for aging interventions are severely limited due to the highly dynamic, interactive and networking nature of life. In addition, this approach limits the number of variables under study, and usually ignores synergistic interactions, thereby oversimplifying the process.

\section{Non Genetically-Modified Mouse Models}

In the group of nongenetically-modified animals, the inbred strain with accelerated senescence SAMP is considered a useful animal model to study aging-related processes (Takeda et al., 1981). The SAMP model allows a shorter waiting time for the animal to grow old and shorter duration of the studies, compared to commonly used old rats and other mouse inbred strains (Goodrick, 1975; Flurkey et al., 2007) (Table 2).

Currently, there are nine SAMP strains (SAMP- 1, 2, 3, 6, 7, 8, 9,10 , and 11) and three SAMR (senescence-accelerated resistant mouse prone) inbred strains (SAMR-1,4, and 5) (Takeda, 1999). The strains were characterized according to certain common characteristics. The strain SAMP-8, SAMP-6 and SAMP-10 were widely used as a model of age-related disease, such as cognitive deficit, due to spontaneous accumulation of amyloid beta plaques similar to Alzheimer's disease, cardiac dysfunction and dysregulation of the immune system (Butterfield and Poon, 2005; Forman et al., 2011). On the other hand, other SAMP strains were reported to present senile osteoporosis (SAMP6); contracted kidney (SAMP1, SAMP11); impaired immune response, hyperinflation of lungs, hearing impairment and hypertensive vascular disease (SAMP1); degenerative temporomandibular joint disease (SAMP3); thymic lymphoblastic lymphoma and abnormal circadian rhythms (SAMP9, SAMP7); cataracts (SAMP9) and brain atrophy (SAMP10) (Takeda, 1999).

Although it should be kept in mind that inbred strains are limited in genetic diversity and, hence, develop phenotypes specific to those strains, they are easy to genetically manipulate and extensive baseline data are available (Goodrick, 1975). On the other hand, outbred mice are more representative of the genetic diversity of humans, but they present alterations in the genome (Kõks et al., 2016).

Many mouse models to study mechanisms of aging have been developed. With an increasing world older population, those models will be extremely important to test aiming to improve future interventions on aging-related diseases. Although mouse models have not always been generally accepted to study the complexity of aging, much of the progress in this field can be attributed to them (Hasty et al., 2003; Burtner and Kennedy, 2010; Kennedy et al., 2014). So far, there are no gold standard markers that classify aging in animals, but the more closely the model resembles the disease situation, the more relevant will be the data generated from them. Here we will highlight some studies in vascular aging featuring males and females, with a spotlight in vascular studies in female and male SAMP mice.

\section{SEX DIFFERENCES IN AGING-ASSOCIATED CVD Cardiovascular Aging Characterization: What is that?}

During the past 2 decades, the sustained efforts to characterize the effects of aging on multiple aspects of cardiovascular structure and function and the dominant aspects of vascular aging have been reported in two major clinical studies: The Framingham cohort study (Framingham Heart Study - FHS) and the Baltimore Longitudinal Study on Aging (BLSA) (Lakatta and Levy, 2003; Alghatrif et al., 2017).

Aging-linked changes are well evident and studied in elastic arteries, such as the aorta and its main branches. In general, aging is associated with the thickening of the wall in large elastic arteries. With the thickness of the intima-media layer of carotid arteries increasing 2-3 times between the 20th and the 90th year of age (Lakatta, 1993; Lakatta and Levy, 2003). The evidence of age-associated arterial mechanical alterations is observed by the third decade of age with sharp declines in aortic strain. Aortic distensibility is the most sensitive marker of aortic aging in individuals $\leq 50$ years of age, beyond the influences of gender, body size, and cardiovascular risk factors (Redheuil et al., 2010).

Nearly $80 \%$ of the total decline of aortic strain occurs before the fifth decade of age and is associated with an exponential increase in femoral-carotid pulse wave velocity as reported in a study with 54 men/57 women, average age of 20-84 years (Redheuil et al., 2010). Preliminary analysis from the BLSA shows that, even though women have a greater increase in pulse pressure with aging, pulse wave velocity is higher in men, due to a more accelerated increase in aortic root diameter in men than women (Lakatta, 2018). However, the observation that pulse wave velocity, which is a good measure of aortic wall stiffness, remains comparable or lower in older women as compared to men, suggests that factors other than aortic wall stiffness may contribute to the higher pulse pressure in women (Alghatrif et al., 2013). The pulse wave velocity is also an independent predictor of the future increases in systolic blood pressure and of incident hypertension (Najjar et al., 2008). An increased pulse wave velocity reflects 3 potential risk factors: increased systolic pressure, widened pulse pressure, and altered vascular wall properties.

The thickness of the vascular wall is related to the composition of the vascular wall (the amount of smooth muscle, elastin fibers and collagen) and the blood pressure that the vessel will be submitted to. Indeed, aging is the strongest predictor of 
arterial stiffness (Vlachopoulos et al., 2010). Post-mortem studies indicated that the aging-related thickening of the aortic wall consists mainly of thickening of the intima layer, even in populations with a low incidence of atherosclerosis (Virmani et al., 1991), being characterized by increased collagen deposition and the presence of disorganized smooth muscle cells (Lakatta et al., 2009).

Past 50 years of age, as central arterial strain becomes reduced, there is an early increase in diastolic blood pressure and mean arterial pressure in both sexes (Franklin et al., 1997; Scuteri et al., 2014). Indeed, diastolic blood pressure is a stronger predictor of coronary heart disease risk than systolic blood pressure or pulse pressure in $\leq 50$ years old adults. With advancing age, as central arteries stiffen, there is a gradual shift from diastolic blood pressure to systolic blood pressure and eventually to pulse pressure as predictors of coronary heart disease risk in elderly (Franklin et al., 2001), with pulse pressure specifically in elderly women. A sex specific combination of aortic stiffening and aortic dilatation in women may account for the monotonic rates at which systolic and diastolic BP change and pulse pressure increases in women, but not in men (Scuteri et al., 2014).

Male SAMP8 (Reed et al., 2011) and female SAMP8 mice fed a western-type diet (Gevaert et al., 2017) have isolated early agedependent diastolic dysfunction related to heart fibrosis in the absence of alterations in systolic function and blood pressure (Reed et al., 2011; Gevaert et al., 2017). SAMP8 male mice exhibit no alterations in arterial elastance, the ratio of ventricularvascular coupling or impaired cardiac myocyte relaxation, indicating that the diastolic dysfunction cannot be explained by increased vascular stiffness or abnormalities in the interaction between the heart and the systemic vasculature. So, perhaps this might represent a good model to study mechanisms of aging-related diastolic dysfunction in males.

The aging heart is subjected to an increasing systolic load imposed by stiffening of the vasculature, a stimulus for left ventricular hypertrophy (Lakatta, 1994). Data from the FHS with 142 subjects ( 63 men/79 women, mean age $57 \pm 9$ years) and the BLSA study with 336 subjects (136 men/200 women, mean age $56 \pm 18$ years) show different perspectives for left ventricular mass with age. In the FHS study left ventricular mass and wall thickness were all greater in men than in women, regardless of adjustment for height or body surface area. Also, there were no changes with age in cavity dimensions in the short-axis plane in either gender (Salton et al., 2002). In the BLSA study, left ventricular long-axis length index, another independent morphometric determinant of left ventricular mass, decreased by $9.2 \%$ through adulthood, but wall thickness increased, resulting in an altered shape, but no change in overall left ventricular mass in women (Hees et al., 2002). Even though systolic load increases between the ages of 50-60 years in both sexes, left ventricular wall thickness seems more important in aging women than men, and cellular necrosis or apoptosis are considered potent players in age-related left ventricular remodeling in men (Olivetti et al., 1995; Hees et al., 2002).

The incidence CVD is lower in premenopausal women compared with age-matched men, yet menopause women surpassed that of men (Virani et al., 2020). Premenopausal women have lower autonomic tone and baroreceptor response as well as better overall vascular function than men of similar age (Barnett et al., 1999; Christou et al., 2005). Postmenopausal women have stiffer arteries than their male counterparts (Mitchell et al., 2008) even after correcting for body size and aortic diameter (Mitchell et al., 2004). Potentially related to declines in ovarian function and estrogen levels, these vascular differences are clinically reflected in patterns of hypertension prevalence over the life course. Indeed, prior to the age of 45 years, more men than women have hypertension; between 45 and 64, hypertension rates are similar between the sexes, and at ages >65 years, more women than men are hypertensive (National Center for Health Statistics, 2015). This emphasizes the need for age/gender specific reference values, and use of gender-different threshold values for cardiovascular medical exams. According to Novella and collaborators (Novella et al., 2012a), the onset of menopause overlaps with aging-associated changes, making it particularly difficult to distinguish between the contributions of aging and the lack of estrogen to vascular damage. Additional studies using animal models of ovariectomy (OVX) and data collected from ovariectomized women in clinical trials will help to clarify this point.

Among the potential mechanisms involved in cardiovascular aging, endothelial dysfunction is central, since arterial remodeling in healthy humans occurs in the context of age-associated endothelial dysfunction (Celermajer et al., 1994), which is also one of the main processes by which aging increases the risk of CVD in both sexes (Celermajer et al., 1994; Gerhard et al., 1996; Taddei et al., 1997; Rodríguez-Mañas et al., 2009) as summed up in Figure 2. Endothelial dysfunction is clearly multifactorial and aging-induced endothelial dysfunction results from an imbalance characterized by increased production of ROS, increased cyclooxygenase (COX)-derived vasoconstrictor factors, and reduced bioavailability of endothelium-derived nitric oxide (NO) (El Assar et al., 2012). But what are exactly the contributions of these mechanisms for endothelial dysfunction in both sexes?

\section{POSSIBLE MECHANISMS WHEREBY SEX DIFFERENCES IMPACT THE VASCULAR AGING PROCESS}

\section{The Endothelium}

Age-related endothelial dysfunction is common to most arteries independently of either vascular bed and species studied (Küng and Lüscher, 1995; Novella et al., 2010; Novella et al., 2013a; Hongo et al., 1988; Haidet et al., 1995; Taddei et al., 1995; Egashira et al., 1993). Decreased endothelium-dependent vasodilation (EDV) is one of the most studied effects of aging in the vascular system. In clinical studies the rate of decline of EDV is different between aged men and women. Men demonstrate a gradual decline after the fourth decade, while women's decline is delayed approximately one decade, but accelerated after menopause (Celermajer et al., 1994; Taddei et al., 1996). Aging is associated with a progressive decline in 
EDV in large conduit arteries (Lieberman et al., 1994; Lieberman et al., 1996) and peripheral resistance vessels (Delp et al., 1995; Higashi et al., 2006; Lloréns et al., 2007; Novella et al., 2013b; Jiménez-Altayó et al., 2013; Costa et al., 2019) in healthy adults. Estrogen treatment ( $1 \mathrm{mg}$ dose for 9 weeks) in postmenopausal women at a relatively young age (average age $55 \pm 7$ years) improved flow-mediated endothelium-dependent dilation (Lieberman et al., 1994; Lieberman et al., 1996). In men, the reduced EDV was improved after infusion of the NO synthase cofactor, tetrahydrobiopterin (BH4) (Higashi et al., 2006).

To understand the mechanisms behind the reduction of EDV in female vascular senescence in mice, researchers have used the SAMP-8 mouse model. SAMP8 mice were used to characterize female vascular aging with and without the deleterious effects of estrogen withdrawal. Aortas of 6- to 7-month-old female SAMP8 mice develop increased contractility and endothelial dysfunction, which is mediated by decreased NO production (Novella et al., 2010; Novella et al., 2013a). However, mesenteric arteries from the same 6- to 7-month-old female SAMP-8 mice show no decrease in endothelium-dependent vasodilation (Jiménez-Altayó et al., 2013), indicating that the functional vascular alterations in female SAMP-8 occur earlier in conductance arteries than in resistance arteries.

The increased vasoconstrictor responses, endothelial dysfunction, and reduced NO production in aorta of female SAMP-8 mice are potentiated by the lack of estrogen, i.e., by OVX performed at 5 months of age. Accordingly, a 4 -weeks treatment with estrogen, started immediately after OVX, improved vascular function (Novella et al., 2013a). Of importance and aligned with clinical data, Costa et al. (2019) demonstrated that estrogen treatment loses its beneficial vascular actions in 6-month-old ovariectomized female SAMP-8 mice, either when administered shortly after OVX or 45 days after OVX, suggesting an important interaction between aging and the onset of estrogen treatment for the vascular function.

Furthermore, vasodilation to acetylcholine is completely inhibited by L-NG-Nitroarginine Methyl Ester (L-NAME) in female SAMP8 mice at the age of 3, 6 and 8 months (Novella et al., 2013b), reinforcing that changes in NO-mediated responses greatly contribute to aging and senescence-associated vascular dysfunction in females. These early aging-related functional alterations in the vascular tree in females seem to appear earlier in conductance arteries than in resistance blood vessels, since they are observed in conductance, but not in resistance arteries (Jiménez-Altayó et al., 2013).

Aortic rings of male (6- to 7-month-old) SAMP8 mice also demonstrated reduced EDV (Lloréns et al., 2007), in agreement with other models (Delp et al., 1995). However, reduced vasodilation to acetylcholine in male SAMP-8 mice is not mediated by vasoconstrictor prostanoids or reduced eNOS expression, but is due to oxidative stress (Lloréns et al., 2007). In aortas of 12 month-old CD-1 male mice, treatment with indomethacin restored the impaired EDV, suggesting an involvement of increased COX-derived vasoconstrictors (Costa et al., 2016). In 12 month-old female CD1 mice, endothelial function is preserved by normal eNOS expression and an increased release of prostacyclin (Costa et al., 2016).
Endothelium-independent vasodilation is determined by measuring vascular responses to $\mathrm{NO}$ donors, as sodium nitroprusside, in mouse models and humans. In clinical studies, endothelium-independent vasodilation is preserved in both older men and premenopausal women in the micro (Gerhard et al., 1996; Desouza et al., 2000; Desouza et al., 2002) and macrocirculation (Taddei et al., 1996; Taddei et al., 2001). However, studies using doppler ultrasound showed that increases in blood flow induced by sodium nitroprusside in brachial and common femoral arteries are reduced in older men (Newcomer et al., 2004). Explanations for these discrepancies are the different blood flow measurement techniques and the wide age range among the older subjects included in the studies.

In animal models, such as 24-month-old male Fischer 344 rats, abdominal aorta, but not iliac and femoral arteries, exhibit decreased sodium nitroprusside-mediated relaxation (Luttrell et al., 2020). In 26-29 month-old male Wistar rats, sodium nitroprusside-induced relaxation was impaired in endothelium-intact, but not in endothelium-denuded aortic rings, suggesting an inhibitory influence of the endothelium on the response to this NO donor (Kim et al., 2011). In contrast, age had no effect on sodium nitroprusside-induced relaxation in thoracic aorta and femoral arteries of 33 monthold female Wistar rats (Barton et al., 1997) or in aortic rings of 30 month-old male Fischer 344 rats (Delp et al., 1995).

Therefore, there is still controversial information about a decreased sensitivity of vascular smooth muscle cells to NO or smooth muscle capacity of vasodilation in aging. Additional studies eliminating the interference of endothelium-derived factors on NO donor-mediated vasodilation in males and females are necessary. Although reduced NO bioavailability is well described in aged men and women, potential sex-dependent effects of antioxidants, or other agents aimed to rescue NO levels, may lead to new insights in this field.

\section{Reactive Oxygen Species}

Oxidative stress, i.e., increased levels of ROS such as superoxide anion $\left(\mathrm{O}_{2}^{-} \bullet\right.$, hydrogen peroxide and hydroxyl radical, and reactive nitrogen species (RNS) such as peroxynitrite (Brandes et al., 2005; Costa et al., 2021), is directly linked to reduced NO bioavailability. The reaction between $\mathrm{NO}$ and $\mathrm{O}_{2}{ }^{-} \bullet$ produces the peroxynitrite radical, a cytotoxic compound that promotes DNA damage. The main sources of $\mathrm{O}_{2}^{-} \cdot$ in blood vessels of older animals and humans are mitochondria (Ungvari et al., 2010; Tang et al., 2014), NADPH oxidase (Hamilton et al., 2001; Lassègue et al., 2012) and uncoupled eNOS (Delp et al., 2008; Li and Förstermann, 2013).

Oxidative stress and pro-inflammatory cytokines, such as tumor necrosis factor- $\alpha$ (TNF- $\alpha$ ) contribute to endothelial dysfunction and large artery stiffening in postmenopausal women. Decreased NO bioavailability is considered a key factor contributing to the impaired endothelium dependent vasodilation in aging. Older adults present higher serum levels of inflammatory cytokines, such as interleukin-6 (IL-6), interleukin-1 (IL-1), TNF- $\alpha$, and interleukin-18 (IL-18) when compared to younger adults (Wei et al., 1992; Hager et al., 1994). 
In addition, serum TNF- $\alpha$ concentrations are increased only in older healthy women (Straub et al., 1998).

Older men, 55-78 years, compared to young men (18-30 years), exhibit higher levels of nitrotyrosine, a marker of oxidative stress, in endothelial cells from the brachial artery and antecubital veins. No differences between the groups were detected for xanthine oxidase, antioxidant cytosolic (Cu/Zn-SOD) and mitochondrial (Mn-SOD) superoxide dismutase, or catalase (Van Der Loo et al., 2000). Also, older men exhibit elevated nicotinamide adenine dinucleotide phosphate $(\mathrm{NAD}(\mathrm{P}) \mathrm{H})$ oxidase subunit p47phox in venous-derived endothelial cells compared with young subjects (Van Der Loo et al., 2000), and administration of vitamin $\mathrm{C}$ restores $\mathrm{EDV}$ in older healthy men (Eskurza et al., 2004; Jablonski et al., 2007). Studies with rodents also showed enhanced vascular $\mathrm{NAD}(\mathrm{P}) \mathrm{H}$ oxidase-derived $\mathrm{O}_{2}{ }^{-} \bullet$ production with unchanged xanthine oxidase-derived $\mathrm{O}_{2}{ }^{-} \bullet$ in arteries from old (18-20 months) compared with young (3-4 months) male Sprague-Dawley rats (Csiszar et al., 2002).

Increased ROS and imbalance of the antioxidants enzymes are a ubiquitous problem in vascular aging in men and women, with greater oxidative stress in men compared to premenopausal women (Ide et al., 2002). It is undeniable that the senior population is more susceptible to oxidative stress conditions, but further studies are needed to understand whether oxidative stress is an intrinsic aging process or, as we get older, we become more susceptible to oxidative injury.

ROS are fundamental to many endothelial cell functions, acting e.g. as signaling molecules that activate proinflammatory processes (Ungvari et al., 2007). ROS activates Nuclear Factor Kappa B (NF-kB) that regulates endothelial activation and expression of proinflammatory mediators, leading to endothelial senescence (Keymel et al., 2008). ROS signal the presence of a defective cell and stimulate progenitor cells to continue to replenish the circulatory system with functional differentiated endothelial and smooth muscle cells. Generally, senescent cells are removed by apoptosis and immune cells. Endothelial senescence should abrogate the process, but the immune system is ineffective in removing these endothelial cells. The extent of immune-system involvement in regulating age-related accumulation of senescent cells, and its consequences, are unknown. However, impaired cell cytotoxicity and defective function of circulating endothelial pluri-potent cells have been reported (Rauscher et al., 2003; Keymel et al., 2008). These defective endothelial cells can further promote senescent-cell accumulation and shorten lifespan, generating a chronic proinflammatory environment where cells continue to signal the immune system (Morgan et al., 2013).

Characterizations of peripheral blood mononuclear cells using ATAC-seq, RNA-seq, and flow cytometry showed less naïve $\mathrm{T}$ cells and increasing monocyte and cytotoxic cell functions in older patients (Márquez et al., 2020). These changes are greater in magnitude in men, and premature immunosenescence (Fuente et al., 2004) is accompanied by a male-specific decline in B-cell specific loci. These results are elegantly discussed by Márquez et al. (2020), and this field should be explored in mouse models of aging, since overactivation of the immune system increases the risk for atherosclerosis in men and pre/post-menopause women.

\section{Vasoconstriction}

Increased vascular constrictor responses in aging may vary depending on the vasoconstrictor agent and vascular bed studied. In general, contractile responses to adrenergic vasoconstrictors and angiotensin-II (Ang II) are increased by chronological aging in female and male mice. Potential mechanisms include decreased endothelial NO synthase expression, reduced NO synthesis, increased ROS production, decreased SOD activity (Bolzán et al., 1997; Inal et al., 2001; Mariani et al., 2006); and increased vasoconstrictor prostanoids, especially in women (Li et al., 2008).

Aging reduces vasoconstriction to potassium chloride $(\mathrm{KCl})$ in 24 month-old male Fischer rats, compared to 4 month-old rats. Removal of the endothelium increases $\mathrm{KCl}$ constrictor responses, but the age-associated decrease in $\mathrm{KCl}$ responsiveness remains (Shipley and Mullerdelp, 2005). Aortic rings of male (6- to 7month-old) SAMP8 mice display greater contractility to $\mathrm{KCl}$ and phenylephrine (Lloréns et al., 2007), which is associated with a decreased modulatory effect of NO, but no alterations in smooth muscle cells function or structure. Angiotensin II-induced vascular contraction increases with aging in male and female CD-1 mice, but is higher in male mice (Costa et al., 2016). Angiotensin II is a key regulator of cell senescence, and modulates the onset and progression of vascular aging (Min et al., 2009; Wang et al., 2010). Increased Ang II responses in aorta of males CD1 mice contribute to endothelial dysfunction by a mechanism that partially involves Ang II-mediated upregulation of COX-derived vasoconstrictors (Costa et al., 2016). Reinforcing these findings, chronic angiotensin converting enzyme (ACE) inhibition, as well as Ang II type 1 (AT1) receptor blockade, recover endothelium-derived hyperpolarizing factor-mediated responses in mesenteric arteries of 12 month-old male Wistar-Kyoto rats (Goto et al., 2004).

It is not clear how prostaglandins are differently produced in aged males and females (Costa et al., 2016). In carotid arteries of 6-month-old female SAMP8 mice, increased phenylephrine vasoconstriction is related to increased Thromboxane $\left(\mathrm{TXA}_{2}\right)$ production. Costa et al. (Costa et al., 2019) showed a differential interaction between estrogens and prostanoids production in menopause. While selective COX-1 or COX-2 inhibitors do not change phenylephrine responses in ovariectomized 6 month-old female SAMP8 mice that underwent an earlytreatment with estrogen, COX inhibition decreases vasoconstrictor responses to phenylephrine in mice that receive a late estrogen-treatment. Further studies showed that aortas of female SAMP8 mice show lower NO levels, and consequently, less NO modulatory effects, in response to $\mathrm{TXA}_{2}$ receptor activation (Novella et al., 2013a). Indeed, prostanoids have a important participation in enhanced constriction in carotid arteries, but not in resistance mesenteric arteries from female SAMP8 mice (Jiménez-Altayó et al., 2013; Costa et al., 2019).

Functional vascular alterations appear earlier than structural changes with aging in male SAMP8 mice. Similarly, flowmediated dilation is preserved in men aged $<$ or $=40$ years 
and declines thereafter at $0.21 \%$ year, but remains preserved in women until the age of 50 years (Celermajer et al., 1994; Skaug et al., 2013). This could be an important information for targeting early signs of CVD in men and women, since coronary artery calcification (Howard et al., 1993), carotid intima-media thickening (Mcclelland et al., 2006) and atherosclerotic plaques are all more common in men than in women (pre-menopause) at young adulthood and middle-age (Kelley et al., 2011).

\section{Perivascular Adipose Tissue}

The perivascular adipose tissue (PVAT) is no longer considered an inert vessel-supporting connective tissue, but an important regulator of vascular tone, exhibiting an anti-contractile effect in response to a variety of vasoconstrictors. This beneficial vasodilatory response is associated with anti-inflammatory effects of PVAT in animal models (Löhn et al., 2002; Dubrovska et al., 2003; Gollasch and Dubrovska, 2004; Verlohren et al., 2004) and in healthy individuals (Greenstein et al., 2009). Alterations in PVAT function may contribute to aging-associated vascular dysfunction and increased cardiovascular risk. However, few research groups have addressed aging-associated alterations in the PVAT, and, so far, the studies performed were carried out only in male animals.

Increased $\mathrm{O}_{2}{ }^{-} \bullet$ signaling (Fleenor et al., 2014) and increased advanced glycation end-products (AGE) accumulation (Ouyang et al., 2017) were reported in thoracic aortic PVAT of 27-29 month-old C57BL/6 male mice. In mesenteric arteries of 12 month-old SAMP8 male mice, PVAT anti-contractile effect to noradrenaline is absent in comparison with SAMR1, but mechanisms were not investigated (Agabiti-rosei et al., 2017). SAMP-8 mice at the age 12 months are close to the end of their lives and may already be riddled with aging-associated multiple disease injuries. These data reinforce the importance of mechanistic and descriptive studies of age-associated changes in PVAT in males and females.

\section{Other Potential Mechanisms}

Considering that hormones that control reproduction modulate mitogenesis and differentiation, the Reproductive-Cell Cycle Theory of Aging states that reproductive hormones negatively regulate aging by promoting growth and development (Atwood et al., 2003; Bowen and Atwood, 2004). According to the theory, the period of maximum reproductive function is linked to the slowest aging period; and as reproductive function begins to decrease, typically during the fourth decade of life, the rate of change in body composition and function, and therefore aging, increases. Here we explore the mechanisms mediated by growth hormone (GH), insulin-like growth factor-1 (IGF1) and reproductive hormones axis on vascular aging.

\section{Growth Hormone and Insulin-Like Growth Factor 1}

In aging, secretion of GH, also known as somatotropin, and IGF1 declines over time, with lowest levels in individuals aged $\geq 60$ years, a phenomenon known as "somatopause" (Junnila et al., 2013). Increased IGF-1 signaling is associated with a decrease in longevity, and inhibition of mTOR by decreased
GH/IGF-1 signaling stimulates autophagy, improving response to cellular stress, and increasing lifespan (Wullschleger et al., 2006; Fontana et al., 2010; Fulda et al., 2010).

Mutations in the IGF-1R gene that reduce IGF-1 signaling have been identified in centenarians (Suh et al., 2008), but men and women with deficiency of $\mathrm{GH}$, thyroid-stimulating hormone (TSH), prolactin, follicle-stimulating hormone (FSH) or luteinizing hormone (LH) have normal longevity (Krzisnik et al., 1999; Besson et al., 2003; Krzisnik et al., 2010); some even reduced mean lifespan (Salvatori et al., 1999; Aguiar-Oliveira et al., 2010).

The cardiovascular system is an important target organ for $\mathrm{GH}$ and IGF-1. There is evidence that cardiac myocytes, vascular endothelial and smooth muscle cells abundantly express IGF1R and that they are more sensitive to IGF-1 than to insulin (Chisalita and Arnqvist, 2004). IGF-1 is important to maintain the functional and structural integrity of the microcirculation. IGF-1 increases NO bioavailability, decreased ROS generation, and has anti-inflammatory, antiapoptotic, and proangiogenic effects (Ungvari and Csiszar, 2012).

Recombinant human GH has been widely used to promote antiaging effects and cardiovascular protection although its efficacy has not been established (Rudman et al., 1990; van den Beld et al., 2003; Denti et al., 2004). Men and women with GH deficiency, who exhibit a pathological and often abrupt decline of GH secretion and, consequently, low levels for their age, show reduced flow-mediated EDV (M Evans et al., 1999), which is restored by GH replacement therapy (Smith et al., 2002). In addition, GH treatment of old individuals with no GH deficiency may increase the risk of other medical conditions (Blackman et al., 2002; Liu et al., 2007).

IGF-1 has significant proangiogenic effects in the heart and brain, inducing proliferation of microvascular endothelial cells through hypoxia-inducible factor 1-alpha (HIF-1 $\alpha$ ) and vascular endothelial growth factor (VEGF), i.e., via the canonical angiogenic pathway (Lopez-Lopez et al., 2004). IGF-1 also prevents oxidative distress by preserving the mitochondrial functional integrity (Li et al., 2009). These effects of IGF-1 on agedependent impairment of angiogenesis are being explored in ischemia and aging neurodegeneration models (Rivard et al., 1999).

Studies linking IGF-1 levels to cardiovascular disease in elderly were inconclusive (Malozowski, 2003; Maggio et al., 2006). In aging, IGF-1 has been shown to recruit cardiomyoblasts, compensating for cell death and preventing ventricular dysfunction (Torella et al., 2004). GH supplementation, which increases circulating levels of IGF-1, increases cortical vascular density (Sonntag et al., 1997) and improves cognitive function in 24-month-old male Brown Norway $\times$ Fisher 344 rats (Ramsey et al., 2004; Sonntag et al., 2005). Treatment of 24-month-old Sprague-Dawley male rats with IGF-1 upregulates eNOS and improves bioavailability of $\mathrm{NO}$ in cavernosal arteries ( $\mathrm{Pu}$ et al., 2008). In addition, age-dependent impairment of endothelial progenitor cells was abrogated by the $\mathrm{GH}$-mediated increase in circulating IGF-1 in sixteen healthy middle-aged male volunteers (mean age $57.4 \pm 1.4$ years) and in aged (6-8 months old) male mice (Thum et al., 2007). Although acute GH-mediated increase in circulating IGF-1 seems to exert beneficial effects on the regenerative capacity of the cardiovascular system in elderly 
men. Data in women volunteers and female models are still needed.

Divergent data support that chronic modulation of IGF-1 promotes arterial obstructive lesions (Bayes-Genis et al., 2000; Higashi et al., 2014), since it induces vascular smooth muscle cell (VSMC) proliferation in vitro (Pfeifle et al., 1987) and increased IGF-1 and IGF-1 receptor have been shown in human and rabbit atherosclerotic arteries (Grant et al., 1996; Grant et al., 1999) compared with normal tissues (Grant et al., 1999). Future studies should elucidate whether age-related IGF1 deficiency is further exacerbated by age-related changes in vascular expression of IGF-1-binding proteins (BPs), IGF-1 receptors or alterations in signaling pathways activated by IGF-1 receptors and whether it increases atherosclerosis risk in men and women.

\section{Sex Hormones in Vascular Aging}

The lower incidence of CVD in premenopausal women, relative to age-matched men, suggests a significant role for female gonadal hormones in the regulation of the vasculature (Mendelsohn and Karas, 2005). Aging per se decreases acetylcholine-induced relaxation, which is further reduced by the removal of ovaries. Accordingly, aging and hormonal status are associated with decreased endothelium-dependent and NOmediated vasodilation (Taddei et al., 1996; Virdis et al., 2000; Teede, 2007). Aged female and male SAMP8 mice reproduce all the morphological (Goyal, 1982), mechanical (Reddy et al., 2003) and endothelial alterations (Blackwell et al., 2004) of the aged human aorta. However, aging-related hormonal changes are not quite similar in mice and humans.

The decline in ovarian function in aging women is usually mimicked by OVX procedures in mouse and rat research models. OVX is often performed due to the lack of natural menopause in rodents in an attempt to reproduce the human hormonal changes. However, most studies have used ovariectomized female rats at young ages (6-12 weeks old) to examine the effects of hormone deprivation in the cardiovascular system. This can lead to unreliable results given that the cardiovascular system has not yet "aged" (Wong et al., 2006).

Testosterone decreases markedly in male SAMP8 mice between 4 and 12 months of age, but the decrease in SAMR1 mice over the same period is not significant, suggesting that SAMP8 gonadal function parallels the decline in cognitive ability (Flood et al., 1995). On the other hand, 6-month-old female SAMP8 mice exhibit hormonal status similar to SAMR1 (Novella et al., 2010; Novella et al., 2013a; Novella et al., 2013b). Thus, SAMP8 mice might represent a valuable model to study the mechanisms of vascular aging at a convenient standard time course (Novella et al., 2010; Novella et al., 2013a) and without overlapping the deleterious effects of estrogen reduction. Of importance, the lack of estrogen protection in SAMP8 mice is not related to age-associated changes in the plasma levels of estrogen or activity of estrogen receptors, but rather to potential age-related changes in estrogen mediated signaling pathways in the vasculature.

Estrogen levels affect arterial distensibility (Gangar et al., 1991). However, there are also non-hormonal differences that affect the behavior of the arterial tree. In men, it is unclear whether endothelial dysfunction occurs with age-associated declines in testosterone in the absence of disease. Crosssectional association studies aiming at serum testosterone levels and endothelial function have shown that low serum testosterone is associated with reduced (average age 52.8 years) (Akishita et al., 2007; Empen et al., 2012) and increased (average age 55.9 years) (Mäkinen et al., 2011) macro- and microvascular endothelial function in men. One reason for these divergent results could be that testosterone concentrations exhibit significant diurnal and day-to-day variations (Bhasin et al., 2018). Another drawback is that the measurement of total testosterone, commonly performed via direct assay (radioimmunoassay, enzymelinked immunosorbent assay, or chemiluminescent immunoassay) has limited accuracy, especially in lower testosterone ranges $(<300 \mathrm{ng} / \mathrm{dl})$, with testosterone concentrations being frequently overestimated (Rosner et al., 2007). Also, measurements of total testosterone include the fraction that is tightly bound to sex hormonebinding globulin (SHBG), which increases with age (Harman et al., 2001) and might be a bias for men with conditions that affect SHBG like obesity, or type 2 diabetes mellitus.

This variation in testosterone measurement is reflected in the clinical setting, and occurrence of low testosterone without symptoms does not meet the definition of "androgen deficiency" set by the Endocrine Society (Bhasin et al., 2018). Although testosterone declines by approximately $1 \%$ per year in men after the third decade (Matsumoto, 2002), decay of bioavailable testosterone is even greater than decay in total testosterone. Consequently, male aging studies should look at modest increases in FSH and LH, impairments in testis function and hypothalamic regulation of gonadotropin secretion that accompanies testosterone decline (Matsumoto, 2002).

\section{Hormonal Receptors Signaling}

Estrogen triggers NO release via estrogen receptor (ER)a-mediated activation of eNOS as well as increased eNOS transcription (Klinge, 2001). Few studies have shown whether aging in female rodents is associated with significant reduction of estrogen-mediated cardiovascular effects. Aging influences the activation of receptors (Novella et al., 2010; Mehta et al., 2019). The discovery of agedependent decline of receptor function emerged in several laboratories during the last decades of the 20th century.

This aspect, the loss of receptors function, is, however, still ignored by physicians, even by geriatricians, in the prescription of drugs and hormones to senior people (Robert and Fulop, 2014). Dr. George Roth research group at the National Institute of Aging (NIA) first showed the aging-dependent decline in muscarinic receptor responsiveness (Joseph et al., 1990). Of importance, aging modulation of receptor signaling seems to occur in both sexes and affects the vascular system equally in men and women (Faury et al., 1997; Robert, 1998; Xiao et al., 1998; Novella et al., 2012b; Moreau et al., 2020).

Detailed analysis suggests that early initiation of estrogen therapy produces more favorable results than the average 
late-onset, which is used in most clinical trials (Grodstein et al., 2006). The so-called "timing hypothesis" (Novella et al., 2010; Novella et al., 2012b) relies on the concept that estrogen has beneficial effects if taken before, or close to, the onset of menopause. Although aging-dependent detrimental effects of estrogen in the vasculature have not yet been demonstrated (Harman et al., 2011), it is possible that aging can determine abnormal responses to therapy in older women, which would be linked to changes in the classical signaling of endogenous hormones.

A key part in maintaining correct cellular function and thus healthiness of the organism is proper gene expression and regulation. Alternative splicing of RNA transcripts, i.e., the formation of alternative splicing receptors, might alter or modulate receptor signaling. Functional experiments in common carotid artery of senescent SAMP8 female mice showed that late-onset of estrogen treatment increases adrenergic vasoconstriction along augmented $\mathrm{TXA}_{2}$ production and upregulation of ER36 expression, an alternative splicing of the classical estrogen receptors (ER) (Costa et al., 2019). Also, an age-related increase in methylation-associated inactivation of genes encoding ERs has been described, and ER methylation in atherosclerotic plaques is higher than in non-plaque regions in vascular tissues (Post et al., 1999; Kim et al., 2007).

Pre-mRNA splicing is an intricate post-transcriptional process that leads to the removal of introns and joining of exons in a premRNA to form a mature mRNA (House and Lynch, 2008). A well-studied example is the Hutchinson Gilford progeria syndrome, where a silent point mutation in the lmna gene adds a 5' splicing signal, leading to a shortened transcript and subsequently a shorter version of its encoded protein Lamina A9 (Liao and Kennedy, 2014). Patients with Hutchinson Gilford progeria syndrome suffer from extensive atherosclerosis and cardiac electrophysiological alterations that invariably lead to premature aging and death (Osorio et al., 2011). Since many components of the RNA processing machinery are themselves regulated by alternative splicing, defects in differential splicing of genes might, therefore, catalyze the aging process via a feed forward mechanism.

Global genome splicing analysis in young and old patients reveals an increased number of alternatively spliced genes related to skin and skeletal muscle (Rodríguez et al., 2016). Since sex hormones are important in cell signaling transcription, further studies are necessary to understand their roles in impaired RNA processing and translation. The role of miRNA and possible miRNA targets in elderly women are elegantly discussed in a review by Pérez-Cremades et al. (2018).

New studies suggest that age-dependent modifications of nuclear hormones may indeed play an important role in the age-dependent decline of several biological functions of vital importance. Studies in mouse models can help to understand the importance of agedependent modifications of receptor function in the vascular system as these effects are accelerated in the SAMP8 mouse, an appropriate model to study vascular effects of aging. It's important to fulfill the gaps on age-dependent endothelial dysfunction in large arteries of males and females and to determine whether this precedes the development of CVD. In the SAMP8 mice, vascular studies should be performed up to 6-7 in males and 8-10 months in females. After 9-10 months SAMP mice begin to develop other pathologies such as insulin resistance, hyperglycemia, hyperinsulinemia and high levels of free fatty acids (Cuesta et al., 2013; Liu et al., 2015).

\section{CLINICAL PERSPECTIVE AND CONCLUSIONS}

Senescence and aging are two distant processes, but they are conceptually intertwined. Women and men grow old, but in different ways. The different mechanisms in vascular aging are associated in part with hormonal changes, inflammation and oxidative stress. Regardless of sex differences in the aging of the cardiovascular system, effective treatment of CVD in women is a challenging issue in medicine, mainly due to the lack of information on the mechanisms involved in the initial stage of CVD, symptoms, and menopause process.

The ability to identify individuals having early deterioration of vascular and cardiac function, as well as progressive subclinical arterial disease, would allow to define a target population for therapy that reduces vascular and cardiac remodeling and dysfunction, and prevents lethal or debilitating events. Considering clinical applications, organismal senescence at the organ level has already been classified in the International Classification of Disease code (ICD) as "intrinsic aging of the skin" and "photoaging of the skin," (Zhavoronkov, 2020), but many diseases within the ICD do not consider ageing in their categorization. In addition, preventive treatment for what is now considered normal cardiovascular aging, may become part of a routine check-up - e.g., a test for endothelial dysfunction, a marker/predictor of vascular aging. Also, reference values should be different in men and women? Should men start vascular checkup at an earlier age than women? Should agingrelated alterations be investigated for preventive treatment? Certainly, results from further studies will contribute to clarify these questions.

\section{AUTHOR CONTRIBUTIONS}

$\mathrm{PB}, \mathrm{TC}$, and RT conceived and designed the review. PB, TC, EA, and RT wrote and critically reviewed the manuscript. PB and TC prepared the figures. All authors approved the submission.

\section{FUNDING}

$\mathrm{PB}$ is a CNPq PhD student fellow (141289/2020-1). TC is a FAPESP post-doctoral fellow (2017/25116-2). RT is supported by a FAPESP grant (2013/08216-2).

\section{ACKNOWLEDGMENTS}

Figures were created under a BioRender.com license. 


\section{REFERENCES}

Advis, J. P., Simpkins, J. W., Chen, H. T., and Meites, J. (1978). Relation of Biogenic Amines to Onset of Puberty in the Female Rat*. Endocrinology 103 (1), 11-16. doi:10.1210/endo-103-1-11

Agabiti-rosei, C., Favero, G., De Ciuceis, C., Rossini, C., Porteri, E., Rodella, L. F., et al. (2017). Effect of Long-Term Treatment with Melatonin on Vascular Markers of Oxidative Stress/inflammation and on the Anticontractile Activity of Perivascular Fat in Aging Mice. Hypertens. Res. 40 (1), 41-50. doi:10.1038/ hr.2016.103

Aguiar-Oliveira, M. H., Oliveira, F. T., Pereira, R. M. C., Oliveira, C. R. P., Blackford, A., Valenca, E. H. O., et al. (2010). Longevity in Untreated Congenital Growth Hormone Deficiency Due to a Homozygous Mutation in the GHRH Receptor Gene. J. Clin. Endocrinol. Metab. 95 (2), 714-721. doi:10.1210/jc.2009-1879

Akishita, M., Hashimoto, M., Ohike, Y., Ogawa, S., Iijima, K., Eto, M., et al. (2007). Low Testosterone Level Is an Independent Determinant of Endothelial Dysfunction in Men. Hypertens. Res. 30 (11), 1029-1034. doi:10.1291/ hypres.30.1029

Alghatrif, M., Strait, J. B., Morrell, C., Canepa, M., Wright, J., Elango, P., et al. (2013). Abstract 18061: Attenuated Aortic Dilatation, Not Increased Wall Stiffness Best Explains the Rise in Pulse Pressure in Women with Aging: Results from the Baltimore Longitudinal Study of Aging. Circulation 128, A18061. doi:10.1161/circ.128.suppl_22.A18061

Alghatrif, M., Wang, M., Fedorova, O. V., Bagrov, A. Y., and Lakatta, E. G. (2017). The Pressure of Aging. Med. Clin. North America 101 (1), 81-101. doi:10.1016/ j.mcna.2016.08.006

Atwood, C. S., Barzilai, N., Bowen, R. L., Brown-Borg, H. M., Jarrard, D. F., Fu, V. X., et al. (2003). Pennington Scientific Symposium on Mechanisms and Retardation of Aging. Exp. Gerontol. 38, 1217-1226. doi:10.1016/ j.exger.2003.08.005

Austad, S. N. (2019). Sex Differences in Health and Aging: a Dialog between the Brain and Gonad?. Geroscience 41 (3), 267-273. doi:10.1007/s11357-01900081-3

Baker, D. J., Jeganathan, K. B., Cameron, J. D., Thompson, M., Juneja, S., Kopecka, A., et al. (2004). BubR1 Insufficiency Causes Early Onset of Aging-Associated Phenotypes and Infertility in Mice. Nat. Genet. 36 (7), 744-749. Epub 2004 Jun 20. PMID: 15208629 . doi:10.1038/ng1382

Baker, D. J., Jeganathan, K. B., Malureanu, L., Perez-Terzic, C., Terzic, A., and van Deursen, J. M. A. (2006). Early Aging-Associated Phenotypes in Bub3/Rae1 Haploinsufficient Mice. J. Cel Biol 172 (4), 529-540. doi:10.1083/jcb.200507081

Baker, D. J., Perez-terzic, C., Jin, F., Pitel, K. S., Niederländer, N. J., Jeganathan, K., et al. (2008). Opposing Roles for p16Ink4a and p19Arf in Senescence and Ageing Caused by BubR1 Insufficiency. Nat. Cel Biol 10 (7), 825-836. doi:10.1038/ncbl744

Bär, C., Povedano, J. M., Serrano, R., Benitez-Buelga, C., Popkes, M., Formentini, I., et al. (2016). Telomerase Gene Therapy Rescues Telomere Length, Bone Marrow Aplasia, and Survival in Mice with Aplastic Anemia. Blood 127, 1770-1779. doi:10.1182/blood-2015-08-667485

Barnett, S. R., Morin, R. J., Kiely, D. K., Gagnon, M., Azhar, G., Knight, E. L., et al. (1999). Effects of Age and Gender on Autonomic Control of Blood Pressure Dynamics. Hypertension 33 (5), 1195-1200. doi:10.1161/01.hyp.33.5.1195

Barnhoorn, S., Uittenboogaard, L. M., Jaarsma, D., Vermeij, W. P., Tresini, M., Weymaere, M., et al. (2014). Cell-autonomous Progeroid Changes in Conditional Mouse Models for Repair Endonuclease XPG Deficiency. Plos Genet. 10, e1004686. doi:10.1371/journal.pgen.1004686

Barton, M., Cosentino, F., Brandes, R. P., Moreau, P., Shaw, S., and Lüscher, T. F. (1997). Anatomic Heterogeneity of Vascular Aging. Hypertension 30 (4), 817-824. doi:10.1161/01.hyp.30.4.817

Bayes-Genis, A., Conover, C. A., and Schwartz, R. S. (2000). The Insulin-like Growth Factor Axis. Circ. Res. 86 (2), 125-130. doi:10.1161/01.res.86.2.125

Beirne, C., Delahay, R., and Young, A. (2015). Sex Differences in Senescence: the Role of Intra-sexual Competition in Early Adulthood. Proc. R. Soc. B. 282, 20151086. doi:10.1098/rspb.2015.1086

Benz, G., Hölzel, D., and Schmoeckel, C. (1991). Inflammatory Cellular Infiltrates in Melanocytic Nevi. The Am. J. Dermatopathology 13 (6), 538-542. doi:10.1097/00000372-199113060-00003
Bergo, M. O., Gavino, B., Ross, J., Schmidt, W. K., Hong, C., Kendall, L. V., et al. (2002). Zmpste24 Deficiency in Mice Causes Spontaneous Bone Fractures, Muscle Weakness, and a Prelamin A Processing Defect. Proc. Natl. Acad. Sci. 99 (20), 13049-13054. doi:10.1073/pnas.192460799

Bernal, G. M., Wahlstrom, J. S., Crawley, C. D., Cahill, K. E., Pytel, P., Liang, H., et al. (2014). Loss of Nfkb1 Leads to Early Onset Aging. Aging (Albany NY) 6 (11), 931-943. doi:10.18632/aging.100702

Besson, A., Salemi, S., Gallati, S., Jenal, A., Horn, R., Mullis, P. S., et al. (2003). Reduced Longevity in Untreated Patients with Isolated Growth Hormone Deficiency. J. Clin. Endocrinol. Metab. 88 (8), 3664-3667. doi:10.1210/jc.2002-021938

Bhasin, S., Brito, J. P., Cunningham, G. R., Hayes, F. J., Hodis, H. N., Matsumoto, A. M., et al. (2018). Testosterone Therapy in Men with Hypogonadism: An Endocrine Society* Clinical Practice Guideline. J. Clin. Endocrinol. Metab. 103 (5), 1715-1744. doi:10.1210/jc.2018-00229

Blackman, M. R., Sorkin, J. D., Münzer, T., Bellantoni, M. F., Busby-Whitehead, J., Stevens, T. E., et al. (2002). Growth Hormone and Sex Steroid Administration in Healthy Aged Women and Men. JAMA 288 (18), 2282-2292. doi:10.1001/ jama.288.18.2282

Blackwell, K. A., Sorenson, J. P., Richardson, D. M., Smith, L. A., Suda, O., Nath, K., et al. (2004). Mechanisms of Aging-Induced Impairment of Endothelium-dependent Relaxation: Role of Tetrahydrobiopterin. Am. J. Physiology-Heart Circulatory Physiol. 287 (6), H2448-H2453. doi:10.1152/ajpheart.00248.2004

Bolzán, A. D., Bianchi, M. S., and Bianchi, N. O. (1997). Superoxide Dismutase, Catalase and Glutathione Peroxidase Activities in Human Blood: Influence of Sex, Age and Cigarette Smoking. Clin. Biochem. 30, 449-454. doi:10.1016/ s0009-9120(97)00047-7

Bowen, R. L., and Atwood, C. S. (2004). Living and Dying for Sex. Gerontology 50, 265-290. doi:10.1159/000079125

Brandes, R., Fleming, I., and Busse, R. (2005). Endothelial Aging. Cardiovasc. Res. 66 (2), 286-294. doi:10.1016/j.cardiores.2004.12.027

Breitschopf, K., Zeiher, A. M., and Dimmeler, S. (2001). Pro-atherogenic Factors Induce Telomerase Inactivation in Endothelial Cells through an Akt-dependent Mechanism. FEBS Lett. 493 (1), 21-25. doi:10.1016/s0014-5793(01)02272-4

Burtner, C. R., and Kennedy, B. K. (2010). Progeria Syndromes and Ageing: what Is the Connection?. Nat. Rev. Mol. Cel Biol 11 (8), 567-578. doi:10.1038/nrm2944

Butterfield, D., and Poon, H. (2005). The Senescence-Accelerated Prone Mouse (SAMP8): A Model of Age-Related Cognitive Decline with Relevance to Alterations of the Gene Expression and Protein Abnormalities in Alzheimer's Disease. Exp. Gerontol. 40, 774-783. doi:10.1016/ j.exger.2005.05.007

Campisi, J. (1997). Aging and Cancer: the Double-Edged Sword of Replicative Senescence. J. Am. Geriatr. Soc. 45 (4), 482-488. doi:10.1111/j.15325415.1997.tb05175.x

Casellas, J., and Medrano, J. F. (2008). Lack of Socs2 Expression Reduces Lifespan in High-Growth Mice. Age (Dordr). 30 (4), 245-249. doi:10.1007/s11357-0089064-1

Celermajer, D. S., Sorensen, K. E., Spiegelhalter, D. J., Georgakopoulos, D., Robinson, J., and Deanfield, J. E. (1994). Aging Is Associated with Endothelial Dysfunction in Healthy Men Years before the Age-Related Decline in Women. J. Am. Coll. Cardiol. 24 (2), 471-476. doi:10.1016/07351097(94)90305-0

Chang, S., Multani, A. S., Cabrera, N. G., Naylor, M. L., Laud, P., Lombard, D., et al. (2004). Essential Role of Limiting Telomeres in the Pathogenesis of Werner Syndrome. Nat. Genet. 36 (8), 877-882. doi:10.1038/ng1389

Chen, H.-y., and Maklakov, A. A. (2014). Condition Dependence of Male Mortality Drives the Evolution of Sex Differences in Longevity. Curr. Biol. 24 (20), 2423-2427. doi:10.1016/j.cub.2014.08.055

Chesky, J. A., and Rockstein, M. (1976). Life Span Characteristics in the Male Fischer Rat. Exp. Aging Res. 2 (5), 399-407. doi:10.1080/03610737608257998

Chisalita, S. I., and Arnqvist, H. J. (2004). Insulin-like Growth Factor I Receptors Are More Abundant Than Insulin Receptors in Human Micro- and Macrovascular Endothelial Cells. Am. J. Physiology-Endocrinology Metab. 286, E896-E901. doi:10.1152/ajpendo.00327.2003

Christou, D. D., Jones, P. P., Jordan, J., Diedrich, A., Robertson, D., and Seals, D. R. (2005). Women Have Lower Tonic Autonomic Support of Arterial Blood Pressure and Less Effective Baroreflex Buffering Than Men. Circulation 111 (4), 494-498. doi:10.1161/01.cir.0000153864.24034.a6 
Coppé, J.-P., Patil, C. K., Rodier, F., Sun, Y., Muñoz, D. P., Goldstein, J., et al. (2008). Senescence-associated Secretory Phenotypes Reveal CellNonautonomous Functions of Oncogenic RAS and the P53 Tumor Suppressor. Plos Biol. 6 (12), e301-68. doi:10.1371/journal.pbio.0060301

Costa, G., Garabito, M., Jiménez-Altayó, F., Onetti, Y., Sabate, M., Vila, E., et al. (2016). Sex Differences in Angiotensin II Responses Contribute to a Differential Regulation of Cox-Mediated Vascular Dysfunction during Aging. Exp. Gerontol. 85, 71-80. doi:10.1016/j.exger.2016.09.020

Costa, T. J., Barros, P. R., Arce, C., Santos, J. D., Da Silva-neto, J., Egea, G., et al. (2021). The Homeostatic Role of Hydrogen Peroxide, Superoxide Anion and Nitric Oxide in the Vasculature. Free Radic. Biol. Med. 162, 615-635. doi:10.1016/j.freeradbiomed.2020.11.021

Costa, T. J., Jiménez-Altayó, F., Echem, C., Akamine, E. H., Tostes, R., Vila, E., et al. (2019). Late Onset of Estrogen Therapy Impairs Carotid Function of Senescent Females in Association with Altered Prostanoid Balance and Upregulation of the Variant ERa36. Cells 8 (10), 1217. doi:10.3390/ cells8101217

Cox, L. S., and Faragher, R. G. A. (2007). From Old Organisms to New Molecules: Integrative Biology and Therapeutic Targets in Accelerated Human Ageing. Cell. Mol. Life Sci. 64, 2620-2641. doi:10.1007/s00018-007-7123-x

Csiszar, A., Ungvari, Z., Edwards, J. G., Kaminski, P., Wolin, M. S., Koller, A., et al. (2002). Aging-induced Phenotypic Changes and Oxidative Stress Impair Coronary Arteriolar Function. Circ. Res. 90, 1159-1166. doi:10.1161/ 01.res.0000020401.61826.ea

Cuesta, S., Kireev, R., García, C., Rancan, L., Vara, E., and Tresguerres, J. A. F. (2013). Melatonin Can Improve Insulin Resistance and Aging-Induced Pancreas Alterations in Senescence-Accelerated Prone Male Mice (SAMP8). Age 35 (3), 659-671. doi:10.1007/s11357-012-9397-7

Da Costa, J. P., Vitorino, R., Silva, G. M., Vogel, C., Duarte, A. C., and RochaSantos, T. (2016). A Synopsis on Aging-Theories, Mechanisms and Future Prospects. Ageing Res. Rev. 29, 90-112. doi:10.1016/j.arr.2016.06.005

de Boer, J., Andressoo, J. O., de Wit, J., Huijmans, J., Beems, R. B., van Steeg, H., et al. (2002). Premature Aging in Mice Deficient in DNA Repair and Transcription. Science 296, 1276-1279. doi:10.1126/science.1070174

De Cecco, M., Criscione, S. W., Peckham, E. J., Hillenmeyer, S., Hamm, E. A., Manivannan, J., et al. (2013). Genomes of Replicatively Senescent Cells Undergo Global Epigenetic Changes Leading to Gene Silencing and Activation of Transposable Elements. Aging Cell 12 (2), 247-256. doi:10.1111/acel.12047

Delp, M. D., Behnke, B. J., Spier, S. A., Wu, G., and Muller-delp, J. M. (2008). Ageing Diminishes Endothelium-dependent Vasodilatation and Tetrahydrobiopterin Content in Rat Skeletal Muscle Arterioles. J. Physiol. 586 (Pt 4), 1161-1168. doi:10.1113/jphysiol.2007.147686

Delp, M. D., Brown, M., Laughlin, M. H., and Hasser, E. M. (1995). Rat Aortic Vasoreactivity Is Altered by Old Age and Hindlimb Unloading. J. Appl. Physiol. 78 (6), 2079-2086. doi:10.1152/jappl.1995.78.6.2079

Denti, L., Annoni, V., Cattadori, E., Angela Salvagnini, M., Visioli, S., Francesca Merli, M., et al. (2004). Insulin-like Growth Factor 1 as a Predictor of Ischemic Stroke Outcome in the Elderly. Am. J. Med. 117 (5), 312-317. doi:10.1016/ j.amjmed.2004.02.049

Desouza, C. A., Clevenger, C. M., Greiner, J. J., Smith, D. T., Hoetzer, G. L., Shapiro, L. F., et al. (2002). Evidence for Agonist-specific Endothelial Vasodilator Dysfunction with Ageing in Healthy Humans. J. Physiol. 542 (Pt 1), 255-262. doi:10.1113/jphysiol.2002.019166

Desouza, C. A., Shapiro, L. F., Clevenger, C. M., Dinenno, F. A., Monahan, K. D., Tanaka, H., et al. (2000). Regular Aerobic Exercise Prevents and Restores AgeRelated Declines in Endothelium-dependent Vasodilation in Healthy Men. Circulation 102 (12), 1351-1357. doi:10.1161/01.cir.102.12.1351

Dollé, M. E. T., Kuiper, R. V., Roodbergen, M., Robinson, J., de Vlugt, S., Wijnhoven, S. W. P., et al. (2011). Broad Segmental Progeroid Changes in Short-Lived Ercc1 -/ $\Delta 7$ Mice. Pathobiology Aging Age-related Dis. 1, 7219. doi:10.3402/pba.v1i0.7219

Dubrovska, G., Verlohren, S., Luft, F. C., and Gollasch, M. (2003). Mechanisms of ADRF Release from Rat Aortic Adventitial Adipose Tissue. Am. J. Physiol. Heart Circ. Physiol. 286 (3), H1107-H1113. doi:10.1152/ajpheart.00656.2003

Dutta, S., and Sengupta, P. (2016). Men and Mice: Relating Their Ages. Life Sci. 152, 244-248. doi:10.1016/j.lfs.2015.10.025

Egashira, K., Inou, T., Hirooka, Y., Kai, H., Sugimachi, M., Suzuki, S., et al. (1993). Effects of Age on Endothelium-dependent Vasodilation of Resistance Coronary
Artery by Acetylcholine in Humans. Circulation 88 (1), 77-81. PMID: 8319359. doi:10.1161/01.cir.88.1.77

El Assar, M., Angulo, J., Vallejo, S., Peiró, C., Sánchez-Ferrer, C. F., and RodríguezMañas, L. (2012). Mechanisms Involved in the Aging-Induced Vascular Dysfunction. Front. Physio. 3, 132. doi:10.3389/fphys.2012.00132

El Khoudary, S. R., Aggarwal, B., Beckie, T. M., Hodis, H. N., Johnson, A. E., Langer, R. D., et al. (2020). Menopause Transition and Cardiovascular Disease Risk: Implications for Timing of Early Prevention: A Scientific Statement from the American Heart Association. Circulation 142 (25), e506-e532. doi:10.1161/ CIR.0000000000000912

Elchuri, S., Oberley, T. D., Qi, W., Eisenstein, R. S., Jackson Roberts, L., Van Remmen, H., et al. (2005). CuZnSOD Deficiency Leads to Persistent and Widespread Oxidative Damage and Hepatocarcinogenesis Later in Life. Oncogene 24 (3), 367-380. doi:10.1038/sj.onc.1208207

Empen, K., Lorbeer, R., Dörr, M., Haring, R., Nauck, M., Gläser, S., et al. (2012). Association of Testosterone Levels with Endothelial Function in Men. Atvb 32 (2), 481-486. doi:10.1161/ATVBAHA.111.232876

Erusalimsky, J. D., and Skene, C. (2009). Mechanisms of Endothelial Senescence. Exp. Physiol. 94 (3), 299-304. doi:10.1113/expphysiol.2008.043133

Erusalimsky, J. D. (2009). Vascular Endothelial Senescence: from Mechanisms to Pathophysiology. J. Appl. Physiol. 106 (1), 326-332. doi:10.1152/ japplphysiol.91353.2008

Eskurza, I., Monahan, K. D., Robinson, J. A., and Seals, D. R. (2004). Effect of Acute and Chronic Ascorbic Acid on Flow-Mediated Dilatation with Sedentary and Physically Active Human Ageing. J. Physiol. 556, 315-324. doi:10.1113/ jphysiol.2003.057042

Espejel, S., Martín, M., Klatt, P., Martín-Caballero, J., Flores, J. M., and Blasco, M. A. (2004). Shorter Telomeres, Accelerated Ageing and Increased Lymphoma in DNA-PKcs-deficient Mice. EMBO Rep. 5, 503-509. doi:10.1038/ sj.embor.7400127

Eveleigh, J. R., Jasdrow, H. H., and Gunner, M. (1983). The Breeding Performance of CD1 Stud Male Mice with Some Comparative Data from BALB/c, PSD and PSDI Strains. Lab. Anim. 17 (3), 230-234. doi:10.1258/002367783781070669

Faury, G., Chabaud, A., Ristori, M. T., Robert, L., and Verdetti, J. (1997). Effect of Age on the Vasodilatory Action of Elastin Peptides. Mech. Ageing Dev. 95, 31-42. doi:10.1016/s0047-6374(96)01842-8

Feldman, H. A., Longcope, C., Derby, C. A., Johannes, C. B., Araujo, A. B., Coviello, A. D., et al. (2002). Age Trends in the Level of Serum Testosterone and Other Hormones in Middle-Aged Men: Longitudinal Results from the Massachusetts Male Aging Study. J. Clin. Endocrinol. Metab. 87 (2), 589-598. doi:10.1210/ jcem.87.2.8201

Fleenor, B. S., Eng, J. S., Sindler, A. L., Pham, B. T., Kloor, J. D., and Seals, D. R. (2014). Superoxide Signaling in Perivascular Adipose Tissue Promotes Agerelated Artery Stiffness. Aging Cell 13 (3), 576-578. doi:10.1111/acel.12196

Flood, J. F., Farr, S. A., Kaiser, F. E., and Morley, J. E. (1995). Age-Related Impairment in Learning but Not Memory in SAMP8 Female Mice. Pharmacol. Biochem. Behav. 50 (4), 661-664. doi:10.1016/0091-3057(94)00338-6

Flurkey, K., Mcurrer, J., and Harrison, D. (2007). "Mouse Models in Aging Research," in The Mouse in Biomedical Research. American College Laboratory Animal Medicine. Fox, J. G., Barthold, S., Davisson, M., Newcomer, C., Quimby, F., and Smith, A., Editors. 2nd Edition (Burlington, MA: Elsevier), 637-672. doi:10.1016/b978-012369454-6/50074-1

Folkow, B., and Svanborg, A. (1993). Physiology of Cardiovascular Aging. Physiol. Rev. 73 (4), 725-764. doi:10.1152/physrev.1993.73.4.725

Fontana, L., Partridge, L., and Longo, V. D. (2010). Extending Healthy Life SpanFfrom Yeast to Humans. Science 328 (5976), 321-326. doi:10.1126/ science.1172539

Forman, K., Vara, E., Garcia, C., Kireev, R., Cuesta, S., Escames, G., et al. (2011). Effect of a Combined Treatment with Growth Hormone and Melatonin in the Cardiological Aging on Male SAMP8 Mice. Journals Gerontol. Ser. A: Biol. Sci. Med. Sci. 66A (8), 823-834. doi:10.1093/gerona/glr083

Franklin, S. S., Gustin, W., Wong, N. D., Larson, M. G., Weber, M. A., Kannel, W. B., et al. (1997). Hemodynamic Patterns of Age-Related Changes in Blood Pressure. Circulation 96 (1), 308-315. doi:10.1161/01.cir.96.1.308

Franklin, S. S., Jacobs, M. J., Wong, N. D., L'Italien, G. J., and Lapuerta, P. (2001). Predominance of Isolated Systolic Hypertension Among Middle-Aged and Elderly US Hypertensives. Hypertension 37 (3), 869-874. doi:10.1161/ 01.hyp.37.3.869 
Freund, A., Patil, C. K., and Campisi, J. (2011). p38MAPK Is a Novel DNA Damage Response-independent Regulator of the Senescence-Associated Secretory Phenotype. EMBO J. 30 (8), 1536-1548. doi:10.1038/emboj.2011.69

Fuente, M. n. D. L., Baeza, I., Guayerbas, N., Puerto, M., Castillo, C., Salazar, V., et al. (2004). Changes with Ageing in Several Leukocyte Functions of Male and Female Rats. Biogerontology 5 (6), 389-400. doi:10.1007/s10522-004-3201-8

Fulda, S., Gorman, A. M., Hori, O., and Samali, A. (2010). Cellular Stress Responses: Cell Survival and Cell Death. Int. J. Cel Biol. 2010, 1-23. doi:10.1155/2010/214074

Gangar, K. F., Vyas, S., Whitehead, M., Crook, D., Meire, H., and Campbell, S. (1991). Pulsatility index in Internal Carotid Artery in Relation to Transdermal Oestradiol and Time since Menopause. Lancet 338, 839-842. doi:10.1016/01406736(91)91500-t

Gardner, M., Bann, D., Wiley, L., Cooper, R., Hardy, R., Nitsch, D., et al. (2014). Gender and Telomere Length: Systematic Review and Meta-Analysis. Exp. Gerontol. 51, 15-27. doi:10.1016/j.exger.2013.12.004

Gerhard, M., Roddy, M.-A., Creager, S. J., and Creager, M. A. (1996). Aging Progressively Impairs Endothelium-dependent Vasodilation in Forearm Resistance Vessels of Humans. Hypertension 27 (4), 849-853. doi:10.1161/ 01.hyp.27.4.849

Gevaert, A. B., Shakeri, H., Leloup, A. J., van Hove, C. E., de Meyer, G. R. Y., Vrints, C. J., et al. (2017). Endothelial Senescence Contributes to Heart Failure with Preserved Ejection Fraction in an Aging Mouse Model. Circ. Heart Fail. 10 (6), e003806. doi:10.1161/CIRCHEARTFAILURE.116.003806

Gewirtz, D. A., Holt, S. E., and Elmore, L. W. (2008). Accelerated Senescence: an Emerging Role in Tumor Cell Response to Chemotherapy and Radiation. Biochem. Pharmacol. 76 (8), 947-957. doi:10.1016/j.bcp.2008.06.024

Gollasch, M., and Dubrovska, G. (2004). Paracrine Role for Periadventitial Adipose Tissue in the Regulation of Arterial Tone. Trends Pharmacol. Sci. 25, 647-653. doi:10.1016/j.tips.2004.10.005

Goodrick, C. L. (1975). Life-span and the Inheritance of Longevity of Inbred Mice. J. Gerontol. 30 (3), 257-263. doi:10.1093/geronj/30.3.257

Goto, K., Fujii, K., Kansui, Y., and Iida, M. (2004). Changes in EndotheliumDerived Hyperpolarizing Factor in Hypertension and Ageing: Response to Chronic Treatment with Renin-Angiotensin System Inhibitors. Clin. Exp. Pharmacol. Physiol. 31 (9), 650-655. doi:10.1111/j.1440-1681.2004.04054.x

Goyal, V. K. (1982). Changes with Age in the Aorta of Man and Mouse. Exp. Gerontol. 17 (2), 127-132. PMID: 7106206. doi:10.1016/0531-5565(82)90046-8

Grant, M. B., Wargovich, T. J., Bush, D. M., Player, D. W., Caballero, S., Foegh, M., et al. (1999). Expression of IGF-1, IGF-1 Receptor and TGF- $\beta$ Following Balloon Angioplasty in Atherosclerotic and normal Rabbit Iliac Arteries: An Immunocytochemical Study. Regul. Peptides 79 (1), 47-53. doi:10.1016/s01670115(98)00027-5

Grant, M. B., Wargovich, T. J., Ellis, E. A., Tarnuzzer, R., Caballero, S., Estes, K., et al. (1996). Expression of IGF-I, IGF-I Receptor and IGF Binding Proteins -1, $-2,-3,-4$ and -5 in Human Atherectomy Specimens. Regul. Peptides 67 (3), 137-144. doi:10.1016/s0167-0115(96)00124-3

Greenstein, A. S., Khavandi, K., Withers, S. B., Sonoyama, K., Clancy, O., Jeziorska, M., et al. (2009). Local Inflammation and Hypoxia Abolish the Protective Anticontractile Properties of Perivascular Fat in Obese Patients. Circulation 119, 1661-1670. doi:10.1161/circulationaha.108.821181

Greider, C. W. (2000). Cellular Responses to Telomere Shortening: Cellular Senescence as a Tumor Suppressor Mechanism. Harvey Lect 96, 33-50.

Grodstein, F., Manson, J. E., and Stampfer, M. J. (2006). Hormone Therapy and Coronary Heart Disease: the Role of Time since Menopause and Age at Hormone Initiation. J. Women's Health 15 (1), 35-44. doi:10.1089/ jwh.2006.15.35

Hager, K., Machein, U., Krieger, S., Platt, D., Seefried, G., and Bauer, J. (1994). Interleukin-6 and Selected Plasma Proteins in Healthy Persons of Different Ages. Neurobiol. Aging 15 (6), 771-772. doi:10.1016/0197-4580(94)90066-3

Haidet, G. C., Wennberg, P. W., and Rector, T. S. (1995). Aging and Vasoreactivity: In Vivo Responses in the Beagle Hindlimb. Am. J. Physiology-Heart Circulatory Physiol. 268 (1), H92-H99. doi:10.1152/ajpheart.1995.268.1.H92

Hamilton, C. A., Brosnan, M. J., Mcintyre, M., Graham, D., and Dominiczak, A. F. (2001). Superoxide Excess in Hypertension and Aging. Hypertension 37, 529-534. doi:10.1161/01.HYP.37.2.529

Harman, S. M., Metter, E. J., Tobin, J. D., Pearson, J., and Blackman, M. R. (2001). Longitudinal Effects of Aging on Serum Total and Free Testosterone Levels in
Healthy Men. J. Clin. Endocrinol. Metab. 86 (2), 724-731. doi:10.1210/ jcem.86.2.7219

Harman, S. M., Vittinghoff, E., Brinton, E. A., Budoff, M. J., Cedars, M. I., Lobo, R. A., et al. (2011). Timing and Duration of Menopausal Hormone Treatment May Affect Cardiovascular Outcomes. Am. J. Med. 124 (3), 199-205. doi:10.1016/ j.amjmed.2010.09.021

Hasty, P., Campisi, J., Hoeijmakers, J., Van Steeg, H., and Vijg, J. (2003). Aging and Genome Maintenance: Lessons from the Mouse?. Science 299 (5611), 1355-1359. doi:10.1126/science.1079161

Hasty, P., and Vijg, J. (2004). Accelerating Aging by Mouse Reverse Genetics: a Rational Approach to Understanding Longevity. Aging Cell 3 (2), 55-65. doi:10.1111/j.1474-9728.2004.00082.x

Hayflick, L., and Moorhead, P. S. (1961). The Serial Cultivation of Human Diploid Cell Strains. Exp. Cel Res. 25, 585-621. doi:10.1016/0014-4827(61) 90192-6

Hees, P. S., Fleg, J. L., Lakatta, E. G., and Shapiro, E. P. (2002). Left Ventricular Remodeling with Age in normal Men versus Women. Am. J. Cardiol. 90 (11), 1231-1236. doi:10.1016/s0002-9149(02)02840-0

Heinemann, L. A. (2005). Aging Males' Symptoms Scale: a Standardized Instrument for the Practice. J. Endocrinol. Invest. 28 (11 Suppl. Proceedings), 34-38.

Hemann, M. T., and Greider, C. W. (1999). G-strand Overhangs on Telomeres in Telomerase-Deficient Mouse Cells. Nucleic Acids Res. 27, 3964-3969. doi:10.1093/nar/27.20.3964

Higashi, Y., Quevedo, H. C., Tiwari, S., Sukhanov, S., Shai, S. Y., Anwar, A., et al. (2014). Interaction between Insulin-like Growth Factor-1 and Atherosclerosis and Vascular Aging. Front. Horm. Res. 43, 107-124. doi:10.1159/000360571

Higashi, Y., Sasaki, S., Nakagawa, K., Kimura, M., Noma, K., Hara, K., et al. (2006). Tetrahydrobiopterin Improves Aging-Related Impairment of Endotheliumdependent Vasodilation through Increase in Nitric Oxide Production. Atherosclerosis 186 (2), 390-395. doi:10.1016/j.atherosclerosis.2005.07.025

Hoare, M., and Narita, M. (2013). Transmitting Senescence to the Cell Neighbourhood. Nat. Cel Biol 15 (8), 887-889. doi:10.1038/ncb2811

Hongo, K., Nakagomi, T., Kassell, N. F., Sasaki, T., Lehman, M., Vollmer, D. G., et al. (1988). Effects of Aging and Hypertension on Endothelium-dependent Vascular Relaxation in Rat Carotid Artery. Stroke 19 (7), 892-897. doi:10.1161/ 01.str.19.7.892

Horstman, A. M., Dillon, E. L., Urban, R. J., and Sheffield-moore, M. (2012). The Role of Androgens and Estrogens on Healthy Aging and Longevity. Journals Gerontol. Ser. A: Biol. Sci. Med. Sci. 67 (11), 1140-1152. doi:10.1093/gerona/ gls068

House, A. E., and Lynch, K. W. (2008). Regulation of Alternative Splicing: More Than Just the ABCs. J. Biol. Chem. 283 (3), 1217-1221. doi:10.1074/ jbc.R700031200

Howard, G., Sharrett, A. R., Heiss, G., Evans, G. W., Chambless, L. E., Riley, W. A., et al. (1993). Carotid Artery Intimal-Medial Thickness Distribution in General Populations as Evaluated by B-Mode Ultrasound. ARIC Investigators. Stroke 24 (9), 1297-1304. doi:10.1161/01.str.24.9.1297

Hunt, S. C., Chen, W., Gardner, J. P., Kimura, M., Srinivasan, S. R., Eckfeldt, J. H., et al. (2008). Leukocyte Telomeres Are Longer in AfricanAmericans Than in Whites: the National Heart, Lung, and Blood Institute Family Heart Study and the Bogalusa Heart Study. Aging Cell 7 (4), 451-458. doi:10.1111/j.14749726.2008.00397.x

Ide, T., Tsutsui, H., Ohashi, N., Hayashidani, S., Suematsu, N., Tsuchihashi, M., et al. (2002). Greater Oxidative Stress in Healthy Young Men Compared with Premenopausal Women. Atvb 22 (3), 438-442. doi:10.1161/hq0302.104515

Inal, M. E., Kanbak, G., and Sunal, E. (2001). Antioxidant Enzyme Activities and Malondialdehyde Levels Related to Aging. Clin. Chim. Acta 305, 75-80. doi:10.1016/s0009-8981(00)00422-8

Jablonski, K. L., Seals, D. R., Eskurza, I., Monahan, K. D., and Donato, A. J. (2007). High-dose Ascorbic Acid Infusion Abolishes Chronic Vasoconstriction and Restores Resting Leg Blood Flow in Healthy Older Men. J. Appl. Physiol. 103, 1715-1721. doi:10.1152/japplphysiol.00533.2007

Jaskelioff, M., Muller, F. L., Paik, J.-H., Thomas, E., Jiang, S., Adams, A. C., et al. (2011). Telomerase Reactivation Reverses Tissue Degeneration in Aged Telomerase-Deficient Mice. Nature 469, 102-106. doi:10.1038/nature09603

Jiménez-Altayó, F., Onetti, Y., Heras, M., Dantas, A. P., and Vila, E. (2013). Western-style Diet Modulates Contractile Responses to Phenylephrine 
Differently in Mesenteric Arteries from Senescence-Accelerated Prone (SAMP8) and Resistant (SAMR1) Mice. AGE 35, 1219-1234. doi:10.1007/ s11357-012-9450-6

Joseph, J. A., and Roth, G. S. (1990). "Loss of Agonist-Receptor Efficacy in Senescence: Possible Decrements in Second Messenger Function and Calcium Mobilization," in The 1990 Sandoz Lectures in Gerontology. Challenges in Aging. Editors Bergener, M., Emini, M., and Stähelin, H. B. (New York: Academic Press), 167-184.

Jun, J.-I., and Lau, L. F. (2010). The Matricellular Protein CCN1 Induces Fibroblast Senescence and Restricts Fibrosis in Cutaneous Wound healing Epub 2010 Jun 6. Erratum in. Nat. Cel BiolNat Cel Biol 1212 (712), 6761249-6761685. doi:10.1038/ncb2070

Junnila, R. K., List, E. O., Berryman, D. E., Murrey, J. W., and Kopchick, J. J. (2013). The GH/IGF-1 axis in Ageing and Longevity. Nat. Rev. Endocrinol. 9 (6), 366-376. doi:10.1038/nrendo.2013.67

Kander, M. C., Cui, Y., and Liu, Z. (2017). Gender Difference in Oxidative Stress: a New Look at the Mechanisms for Cardiovascular Diseases. J. Cell. Mol. Med. 21 (5), 1024-1032. doi: $10.1111 / \mathrm{jcmm} .13038$

Kaplon, J., Zheng, L., Meissl, K., Chaneton, B., Selivanov, V. A., Mackay, G., et al. (2013). A Key Role for Mitochondrial Gatekeeper Pyruvate Dehydrogenase in OncogeneInduced Senescence. Nature 498 (7452), 109-112. doi:10.1038/nature12154

Kelley, R. E., Dasmahapatra, P., Wang, J., Chen, W., Srinivasan, S. R., Fernandez, C., et al. (2011). Prevalence of Atherosclerotic Plaque in Young and MiddleAged Asymptomatic Individuals. South. Med. J. 104 (12), 803-808. doi:10.1097/ SMJ.0b013e318236c35c

Kennedy, B. K., Berger, S. L., Brunet, A., Campisi, J., Cuervo, A. M., Epel, E. S., et al. (2014). Geroscience: Linking Aging to Chronic Disease. Cell 159 (4), 709-713. doi:10.1016/j.cell.2014.10.039

Keymel, S., Kalka, C., Rassaf, T., Yeghiazarians, Y., Kelm, M., and Heiss, C. (2008). Impaired Endothelial Progenitor Cell Function Predicts Age-dependent Carotid Intimal Thickening. Basic Res. Cardiol. 103, 582-586. doi:10.1007/s00395-008-0742-z

Kim, J., Kim, J. Y., Song, K. S., Lee, Y. H., Seo, J. S., Jelinek, J., et al. (2007). Epigenetic Changes in Estrogen Receptor $\beta$ Gene in Atherosclerotic Cardiovascular Tissues and in-vitro Vascular Senescence. Biochim. Biophys. Acta (Bba) - Mol. Basis Dis. 1772 (1), 72-80. doi:10.1016/j.bbadis.2006.10.004

Kim, S. Y., Park, J. T., Park, J. K., Lee, J. S., and Choi, J. C. (2011). Aging Impairs Vasodilatory Responses in Rats. Korean J. Anesthesiol 61 (6), 506-510. doi:10.4097/kjae.2011.61.6.506

Kipling, D., Davis, T., Ostler, E. L., and Faragher, R. G. (2004). What Can Progeroid Syndromes Tell Us about Human Aging?. Science 305 (5689), 1426-1431. doi:10.1126/science.1102587

Klinge, C. M. (2001). Estrogen Receptor Interaction with Estrogen Response Elements. Nucleic Acids Res. 29 (14), 2905-2919. PMID: 11452016; PMCID: PMC55815. doi:10.1093/nar/29.14.2905

Kõks, S., Dogan, S., Tuna, B. G., González-Navarro, H., Potter, P., and Vandenbroucke, R. E. (2016). Mouse Models of Ageing and Their Relevance to Disease. Mech. Ageing Dev. 160, 41-53. doi:10.1016/j.mad.2016.10.001

Kovacic, J. C., Moreno, P., Hachinski, V., Nabel, E. G., and Fuster, V. (2011). Cellular Senescence, Vascular Disease, and Aging. Circulation 123, 1650-1660. doi:10.1161/circulationaha.110.007021

Krizhanovsky, V., Yon, M., Dickins, R. A., Hearn, S., Simon, J., Miething, C., et al. (2008). Senescence of Activated Stellate Cells Limits Liver Fibrosis. Cell 134 (4), 657-667. doi:10.1016/j.cell.2008.06.049

Krzisnik, C., Grgurić, S., Cvijović, K., and Laron, Z. (2010). Longevity of the Hypopituitary Patients from the Island Krk: a Follow-Up Study. Pediatr. Endocrinol. Rev. 7 (4), 357-362.

Krzisnik, C., Kolacio, Z., Battelino, T., Brown, M., Parks, J. S., and Laron, Z. (1999). The "Little People" of the Island of Krk - Revisited. Etiology of Hypopituitarism Revealed. J. Endocr. Genet. 1, 9-19. doi:10.1515/IJDHD.1999.1.1.9

Kudlow, B. A., Kennedy, B. K., and Monnat, R. J. (2007). Werner and HutchinsonGilford Progeria Syndromes: Mechanistic Basis of Human Progeroid Diseases. Nat. Rev. Mol. Cel Biol 8, 394-404. doi:10.1038/nrm2161

Kühn, R., Löhler, J., Rennick, D., Rajewsky, K., and Müller, W. (1993). Interleukin10-deficient Mice Develop Chronic Enterocolitis. Cell 75 (2), 263-274. doi:10.1016/0092-8674(93)80068-p

Kuro-o, M., Matsumura, Y., Aizawa, H., Kawaguchi, H., Suga, T., Utsugi, T., et al. (1997). Mutation of the Mouse Klotho Gene Leads to a Syndrome Resembling Ageing. Nature 390, 45-51. doi:10.1038/36285
Kurz, D. J., Decary, S., Hong, Y., Trivier, E., Akhmedov, A., and Erusalimsky, J. D. (2004). Chronic Oxidative Stress Compromises Telomere Integrity and Accelerates the Onset of Senescence in Human Endothelial Cells. J. Cel Sci 117 (Pt 11), 2417-2426. doi:10.1242/jcs.01097

Kurz, D. J., Hong, Y., Trivier, E., Huang, H.-L., Decary, S., Zang, G. H., et al. (2003). Fibroblast Growth Factor-2, but Not Vascular Endothelial Growth Factor, Upregulates Telomerase Activity in Human Endothelial Cells. Atvb 23 (5), 748-754. doi:10.1161/01.ATV.0000069624.55424.61

Küng, C. F., and Lüscher, T. F. (1995). Different Mechanisms of Endothelial Dysfunction with Aging and Hypertension in Rat Aorta. Hypertension 25 (2), 194-200. doi:10.1161/01.hyp.25.2.194

Kyo, S., Takakura, M., Kanaya, T., Zhuo, W., Fujimoto, K., Nishio, Y., et al. (1999). Estrogen Activates Telomerase. Cancer Res. 59 (23), 5917-5921.

Lakatta, E. G. (1993). Cardiovascular Regulatory Mechanisms in Advanced Age. Physiol. Rev. 73 (2), 413-467. doi:10.1152/physrev.1993.73.2.413

Lakatta, E. G. (1994). Cardiovascular reserve Capacity in Healthy Older Humans. Aging Clin. Exp. Res. 6 (4), 213-223. doi:10.1007/BF03324244

Lakatta, E. G., and Levy, D. (2003). Arterial and Cardiac Aging: Major Shareholders in Cardiovascular Disease Enterprises. Circulation 107, 139-146. doi:10.1161/ 01.CIR.0000048892.83521.58

Lakatta, E. G. (2018). The Reality of Getting Old. Nat. Rev. Cardiol. 15, 499-500. doi:10.1038/s41569-018-0068-y

Lakatta, E. G., Wang, M., and Najjar, S. S. (2009). Arterial Aging and Subclinical Arterial Disease Are Fundamentally Intertwined at Macroscopic and Molecular Levels. Med. Clin. North America 93 (3), 583-604. doi:10.1016/j.mcna.2009.02.008

Lassègue, B., San Martín, A., and Griendling, K. K. (2012). Biochemistry, Physiology, and Pathophysiology of NADPH Oxidases in the Cardiovascular System. Circ. Res. 110 (10), 1364-1390. doi:10.1161/CIRCRESAHA.111.243972

Lees, H., Walters, H., and Cox, L. S. (2016). Animal and Human Models to Understand Ageing. Maturitas 93, 18-27. doi:10.1016/j.maturitas.2016.06.008

Leri, A., Malhotra, A., Liew, C.-C., Kajstura, J., and Anversa, P. (2000). Telomerase Activity in Rat Cardiac Myocytes Is Age and Gender Dependent. J. Mol. Cell Cardiol. 32 (3), 385-390. doi:10.1006/jmcc.1999.1084

Levy, M. Z., Allsopp, R. C., Futcher, A. B., Greider, C. W., and Harley, C. B. (1992). Telomere End-Replication Problem and Cell Aging. J. Mol. Biol. 225, 951-960. doi:10.1016/0022-2836(92)90096-3

Li, H., and Förstermann, U. (2013). Uncoupling of Endothelial NO Synthase in Atherosclerosis and Vascular Disease. Curr. Opin. Pharmacol. 13, 161-167. doi:10.1016/j.coph.2013.01.006

Li, H., Vogel, H., Holcomb, V. B., Gu, Y., and Hasty, P. (2007). Deletion of Ku70, Ku80, or Both Causes Early Aging without Substantially Increased Cancer. Mol. Cel Biol 27, 8205-8214. doi:10.1128/MCB.00785-07

Li, M., Kuo, L., and Stallone, J. N. (2008). Estrogen Potentiates Constrictor Prostanoid Function in Female Rat Aorta by Upregulation of Cyclooxygenase-2 and Thromboxane Pathway Expression. Am. J. Physiology-Heart Circulatory Physiol. 294, H2444-H2455. doi:10.1152/ajpheart.01121.2007

Li, Y., Huang, T.-T., Carlson, E. J., Melov, S., Ursell, P. C., Olson, J. L., et al. (1995). Dilated Cardiomyopathy and Neonatal Lethality in Mutant Mice Lacking Manganese Superoxide Dismutase. Nat. Genet. 11 (4), 376-381. doi:10.1038/ ng1295-376

Li, Y., Wu, H., Khardori, R., Song, Y.-H., Lu, Y. W., and Geng, Y.-J. (2009). Insulinlike Growth Factor-1 Receptor Activation Prevents High Glucose-Induced Mitochondrial Dysfunction, Cytochrome-C Release and Apoptosis. Biochem. Biophysical Res. Commun. 384, 259-264. doi:10.1016/j.bbrc.2009.04.113

Liao, C.-Y., and Kennedy, B. K. (2014). Mouse Models and Aging. Curr. Top. Dev. Biol. 109, 249-285. doi:10.1016/B978-0-12-397920-9.00003-2

Lieberman, E. H., Gerhard, M. D., Uehata, A., Selwyn, A. P., Ganz, P., Yeung, A. C., et al. (1996). Flow-induced Vasodilation of the Human Brachial Artery Is Impaired in Patients. Am. J. Cardiol. 78 (11), 1210-1214. doi:10.1016/s00029149(96)00597-8

Lieberman, E. H., Gerhard, M. D., Uehata, A., Walsh, B. W., Selwyn, A. P., Ganz, P., et al. (1994). Estrogen Improves Endothelium-dependent, Flow-Mediated Vasodilation in Postmenopausal Women. Ann. Intern. Med. 121 (12), 936-941. doi:10.7326/0003-4819-121-12-199412150-00005

Liu, H.-W., Chan, Y.-C., Wang, M.-F., Wei, C.-C., and Chang, S.-J. (2015). Dietary (-)-Epigallocatechin-3-Gallate Supplementation Counteracts Aging-Associated Skeletal Muscle Insulin Resistance and Fatty Liver in Senescence-Accelerated Mouse. J. Agric. Food Chem. 63 (38), 8407-8417. doi:10.1021/acs.jafc.5b02501 
Liu, H., Bravata, D. M., Olkin, I., Nayak, S., Roberts, B., Garber, A. M., et al. (2007). Systematic Review: the Safety and Efficacy of Growth Hormone in the Healthy Elderly. Ann. Intern. Med. 146 (2), 104-115. doi:10.7326/0003-4819-146-2200701160-00005

Lloréns, S., De Mera, R. M. M.-F., Pascual, A., Prieto-Martín, A., Mendizábal, Y., De Cabo, C., et al. (2007). The Senescence-Accelerated Mouse (SAM-P8) as a Model for the Study of Vascular Functional Alterations during Aging. Biogerontology 8 (6), 663-672. doi:10.1007/s10522-007-9108-4

Löhn, M., Dubrovska, G., Lauterbach, B., Luft, F. C., Gollasch, M., and Sharma, A. M. (2002). Periadventitial Fat Releases a Vascular Relaxing Factor. FASEB j. 16, 1057-1063. doi:10.1096/fj.02-0024com

Lopez-Lopez, C., LeRoith, D., and Torres-Aleman, I. (2004). Insulin-like Growth Factor I Is Required for Vessel Remodeling in the Adult Brain. Proc. Natl. Acad. Sci. 101, 9833-9838. doi:10.1073/pnas.0400337101

López-Otín, C., Blasco, M. A., Partridge, L., Serrano, M., and Kroemer, G. (2013). The Hallmarks of Aging. Cell 153 (6), 1194-1217. doi:10.1016/j.cell.2013.05.039

Lu, K. H., Hopper, B. R., Vargo, T. M., and Yen, S. S. C. (1979). Chronological Changes in Sex Steroid, Gonadotropin and Prolactin Secretion in Aging Female Rats Displaying Different Reproductive States1. Biol. Reprod. 21 (1), 193-203. doi:10.1095/biolreprod21.1.193

Luttrell, M., Kim, H., Shin, S. Y., Holly, D., Massett, M. P., and Woodman, C. R. (2020). Heterogeneous Effect of Aging on Vasorelaxation Responses in Large and Small Arteries. Physiol. Rep. 8 (1), e14341. doi:10.14814/phy2.14341

M Evans, L. M., Davies, J. S., Goodfellow, J., Rees, J. A., and Scanlon, M. F. (1999). Endothelial Dysfunction in Hypopituitary Adults with Growth Hormone Deficiency. Clin. Endocrinol. 50 (4), 457-464. doi:10.1046/j.1365-2265.1999.00671.x

Maggio, M., Ble, A., Ceda, G. P., and Metter, E. J. (2006). Decline in Insulin-like Growth Factor-I Levels across Adult Life Span in Two Large Population Studies. The Journals Gerontol. Ser. A 61 (issue 2), 182-183. doi:10.1093/gerona/61.2.182

Mäkinen, J. I., Perheentupa, A., Irjala, K., Pöllänen, P., Mäkinen, J., Huhtaniemi, I., et al. (2011). Endogenous Testosterone and Brachial Artery Endothelial Function in Middle-Aged Men with Symptoms of Late-Onset Hypogonadism. The Aging Male 14 (4), 237-242. doi:10.3109/13685538.2011.593655

Maklakov, A. A., and Lummaa, V. (2013). Evolution of Sex Differences in Lifespan and Aging: Causes and Constraints. Bioessays 35 (8), 717-724. doi:10.1002/ bies. 201300021

Malozowski, S. (2003). Use of Growth Hormone in Elderly Individuals. JAMA: J. Am. Med. Assoc. 290 (4), 462-a. PMID: 12876088. doi:10.1001/ jama.290.4.462-b

Mariani, E., Cornacchiola, V., Polidori, M. C., Mangialasche, F., Malavolta, M., Cecchetti, R., et al. (2006). Antioxidant Enzyme Activities in Healthy Old Subjects: Influence of Age, Gender and Zinc Status. Biogerontology 7 (5-6), 391-398. doi:10.1007/s10522-006-9054-6

Márquez, E. J., Chung, C.-h., Marches, R., Rossi, R. J., Nehar-belaid, D., Eroglu, A., et al. (2020). Sexual-dimorphism in Human Immune System Aging. Nat. Commun. 11 (1), 751. doi:10.1038/s41467-020-14396-9

Maskey, R. S., Kim, M. S., Baker, D. J., Childs, B., Malureanu, L. A., Jeganathan, K. B., et al. (2014). Spartan Deficiency Causes Genomic Instability and Progeroid Phenotypes. Nat. Commun. 5, 5744. doi:10.1038/ncomms6744

Matsumoto, A. M. (2002). Andropause: Clinical Implications of the Decline in Serum Testosterone Levels with Aging in Men. Journals Gerontol. Ser. A: Biol. Sci. Med. Sci. 57 (2), M76-M99. doi:10.1093/gerona/57.2.m76.1

Mcclelland, R. L., Chung, H., Detrano, R., Post, W., and Kronmal, R. A. (2006). Distribution of Coronary Artery Calcium by Race, Gender, and Age. Circulation 113 (1), 30-37. doi:10.1161/CIRCULATIONAHA.105.580696

Mehta, J. M., Chester, R. C., and Kling, J. M. (2019). The Timing Hypothesis: Hormone Therapy for Treating Symptomatic Women during Menopause and its Relationship to Cardiovascular Disease. J. Women's Health 28 (5), 705-711. doi:10.1089/jwh.2018.7201

Mendelsohn, M. E., and Karas, R. H. (2005). Molecular and Cellular Basis of Cardiovascular Gender Differences. Science 308 (5728), 1583-1587. doi:10.1126/science.1112062

Mercken, E. M., Hu, J., Krzysik-Walker, S., Wei, M., Li, Y., McBurney, M. W., et al. (2014). SIRT1 but Not its Increased Expression Is Essential for Lifespan Extension in Caloric-Restricted Mice. Aging Cell 13 (1), 193-196. doi:10.1111/acel.12151

Miller, R. A. (2004). 'Accelerated Aging': a Primrose Path to Insight?. Aging Cell 3 (2), 47-51. doi:10.1111/j.1474-9728.2004.00081.x
Miller, R. A., and Nadon, N. L. (2000). Principles of Animal Use for Gerontological Research. Journals Gerontol. Ser. A: Biol. Sci. Med. Sci. 55 (3), B117-B123. doi:10.1093/gerona/55.3.b117

Min, L.-J., Mogi, M., Iwai, M., and Horiuchi, M. (2009). Signaling Mechanisms of Angiotensin II in Regulating Vascular Senescence. Ageing Res. Rev. 8 (2), 113-121. doi:10.1016/j.arr.2008.12.002

Mitchell, G. F., Gudnason, V., Launer, L. J., Aspelund, T., and Harris, T. B. (2008). Hemodynamics of Increased Pulse Pressure in Older Women in the Community-Based Age, Gene/Environment Susceptibility-Reykjavik Study. Hypertension 51 (4), 1123-1128. doi:10.1161/ hypertensionaha.107.108175

Mitchell, G. F., Parise, H., Benjamin, E. J., Larson, M. G., Keyes, M. J., Vita, J. A., et al. (2004). Changes in Arterial Stiffness and Wave Reflection with Advancing Age in Healthy Men and Women. Hypertension 43 (6), 1239-1245. doi:10.1161/ 01.hyp.0000128420.01881.aa

Mitchell, S. J., Scheibye-knudsen, M., Longo, D. L., and De Cabo, R. (2015). Animal Models of Aging Research: Implications for Human Aging and Age-Related Diseases. Annu. Rev. Anim. Biosci. 3, 283-303. doi:10.1146/annurev-animal022114-110829

Moreau, K. L., Babcock, M. C., and Hildreth, K. L. (2020). Sex Differences in Vascular Aging in Response to Testosterone. Biol. Sex. Differ. 11 (1), 18. doi:10.1186/s13293-020-00294-8

Morgan, R. G., Ives, S. J., Lesniewski, L. A., Cawthon, R. M., Andtbacka, R. H. I., Noyes, R. D., et al. (2013). Age-related Telomere Uncapping Is Associated with Cellular Senescence and Inflammation Independent of Telomere Shortening in Human Arteries. Am. J. Physiology-Heart Circulatory Physiol. 305, H251-H258. doi:10.1152/ajpheart.00197.2013

Moskovitz, J., Bar-Noy, S., Williams, W. M., Requena, J., and Berlett, B. S. (2001). Stadtman Methionine Sulfoxide Reductase (MsrA) Is a Regulator of Antioxidant Defense and Lifespan in Mammals. Proc. Natl. Acad. Sci. United States America 98, 12920-12925. doi:10.1073/pnas.231472998

Mostoslavsky, R., Chua, K. F., Lombard, D. B., Pang, W. W., Fischer, M. R., Gellon, L., et al. (2006). Genomic Instability and Aging-like Phenotype in the Absence of Mammalian SIRT6. Cell 124, 315-329. doi:10.1016/j.cell.2005.11.044

Mounkes, L. C., Kozlov, S., Hernandez, L., Sullivan, T., and Stewart, C. L. (2003). A Progeroid Syndrome in Mice Is Caused by Defects in A-type Lamins. Nature 423 (6937), 298-301. doi:10.1038/nature01631

Muñoz-Espín, D., Cañamero, M., Maraver, A., Gómez-López, G., Contreras, J., Murillo-cuesta, S., et al. (2013). Programmed Cell Senescence during Mammalian Embryonic Development. Cell 155 (5), 1104-1118. doi:10.1016/ j.cell.2013.10.019

Murga, M., Bunting, S., Montaña, M. F., Soria, R., Mulero, F., Cañamero, M., et al. (2009). A Mouse Model of ATR-Seckel Shows Embryonic Replicative Stress and Accelerated Aging. Nat. Genet. 41 (8), 891-898. doi:10.1038/ng.420

Musarò, A., and Rosenthal, N. (1999). Transgenic Mouse Models of Muscle Aging. Exp. Gerontol. 34 (2), 147-156. doi:10.1016/s0531-5565(98)00079-5

Nadon, N. L. (2006). Of Mice and Monkeys: National Institute on Aging Resources Supporting the Use of Animal Models in Biogerontology Research. Journals Gerontol. Ser. A: Biol. Sci. Med. Sci. 61 (8), 813-815. PMID: 16912097. doi:10.1093/gerona/61.8.813

Najjar, S. S., Scuteri, A., Shetty, V., Wright, J. G., Muller, D. C., Fleg, J. L., et al. (2008). Pulse Wave Velocity Is an Independent Predictor of the Longitudinal Increase in Systolic Blood Pressure and of Incident Hypertension in the Baltimore Longitudinal Study of Aging. J. Am. Coll. Cardiol. 51 (14), 1377-1383. doi:10.1016/j.jacc.2007.10.065

Nakamura, E., and Miyao, K. (2008). Sex Differences in Human Biological Aging. Journals Gerontol. Ser. A: Biol. Sci. Med. Sci. 63 (9), 936-944. doi:10.1093/ gerona/63.9.936

National Center for Health Statistics (2015). Health, United States, 2014: With Special Feature on Adults Aged 55-64. Report No: 2015-1232. Hyattsville (MD): National Center for Health Statistics (US).

National Human Genome Research Institute (2021). Animal Models. Available at: https://www.genome.gov/genetics-glossary/Animal-Model (Accessed June 18, 2021).

Neumann, C. A., Krause, D. S., Carman, C. V., Das, S., Dubey, D. P., Abraham, J. L., et al. (2003). Essential Role for the Peroxiredoxin Prdx1 in Erythrocyte Antioxidant Defence and Tumour Suppression. Nature 424 (6948), 561-565. doi:10.1038/nature01819 
Newcomer, S. C., Leuenberger, U. A., Hogeman, C. S., Handly, B. D., and Proctor, D. N. (2004). Different Vasodilator Responses of Human Arms and Legs. J. Physiol. 556 (Pt 3), 1001-1011. doi:10.1113/jphysiol.2003.059717

Nordfjäll, K., Larefalk, A., Lindgren, P., Holmberg, D., and Roos, G. (2005). Telomere Length and Heredity: Indications of Paternal Inheritance. Proc. Natl. Acad. Sci. 102 (45), 16374-16378. doi:10.1073/pnas.0501724102

Novella, S., Dantas, A. P., Segarra, G., Medina, P., and Hermenegildo, C. (2012). Vascular Aging in Women: Is Estrogen the Fountain of Youth?. Front. Physio. 3, 165. doi:10.3389/fphys.2012.00165

Novella, S., Dantas, A. P., Segarra, G., Novensà, L., Bueno, C., Heras, M., et al. (2010). Gathering of Aging and Estrogen Withdrawal in Vascular Dysfunction of Senescent Accelerated Mice. Exp. Gerontol. 45 (11), 868-874. doi:10.1016/ j.exger.2010.07.007

Novella, S., Dantas, A. P., Segarra, G., Novensa, L., Heras, M., Hermenegildo, C., et al. (2013). Aging Enhances Contraction to Thromboxane A2 in Aorta from Female Senescence-Accelerated Mice. Age 35 (1), 117-128. doi:10.1007/s11357011-9337-y

Novella, S., Dantas, A. P., Segarra, G., Vidal-Gómez, X., Mompeón, A., Garabito, M., et al. (2013). Aging-related Endothelial Dysfunction in the Aorta from Female Senescence-Accelerated Mice Is Associated with Decreased Nitric Oxide Synthase Expression. Exp. Gerontol. 48, 1329-1337. doi:10.1016/j.exger.2013.08.003

Novella, S., Heras, M., Hermenegildo, C., and Dantas, A. P. (2012). Effects of Estrogen on Vascular Inflammation. Atvb 32 (8), 2035-2042. doi:10.1161/ ATVBAHA.112.250308

NuzhdinMackay, S. V. T. F., and Mackay, T. F. C. (1994). Direct Determination of Retrotransposon Transposition Rates in Drosophila melanogaster. Genet. Res. 63, 139-144. doi:10.1017/s0016672300032249

Olivetti, G., Giordano, G., Corradi, D., Melissari, M., Lagrasta, C., Gambert, S. R., et al. (1995). Gender Differences and Aging: Effects on the Human Heart. J. Am. Coll. Cardiol. 26 (4), 1068-1079. doi:10.1016/0735-1097(95)00282-8

Olovnikov, A. M. (1973). A Theory of Marginotomy. The Incomplete Copying of Template Margin in Enzymic Synthesis of Polynucleotides and Biological Significance of the Phenomenon. J. Theor. Biol. 41, 181-190. doi:10.1016/ 0022-5193(73)90198-7

Olovnikov, A. M. (1971). Principle of Marginotomy in Template Synthesis of Polynucleotides. Dokl. Akad. Nauk. SSSR 201, 1496-1499.

Osorio, F. G., Navarro, C. L., Cadiñanos, J., López-mejía, I. C., Quirós, P. M., Bartoli, C., et al. (2011). Splicing-directed Therapy in a New Mouse Model of Human Accelerated Aging. Sci. Translational Med. 3 (106), $106 \mathrm{ra} 107$. doi:10.1126/scitranslmed.3002847

Ouyang, A., Garner, T. B., and Fleenor, B. S. (2017). Hesperidin Reverses Perivascular Adipose-Mediated Aortic Stiffness with Aging. Exp. Gerontol. 97, 68-72. doi:10.1016/j.exger.2017.08.003

Pendás, A. M., Zhou, Z., Cadiñanos, J., Freije, J. M. P., Wang, J., Hultenby, K., et al. (2002). Defective Prelamin A Processing and Muscular and Adipocyte Alterations in Zmpste24 Metalloproteinase-Deficient Mice. Nat. Genet. 31, 94-99. doi:10.1038/ng871

Pérez-Cremades, D., Mompeón, A., Vidal-Gómez, X., Hermenegildo, C., and Novella, S. (2018). Role of miRNA in the Regulatory Mechanisms of Estrogens in Cardiovascular Ageing. Oxidative Med. Cell Longevity 2018, 1-16. doi:10.1155/2018/6082387

Pfeifle, B., Hamann, H., Fussganger, R., and Ditschuneit, H. (1987). Insulin as a Growth Regulator of Arterial Smooth Muscle Cells: Effect of Insulin of I.G.F.I. Diabete Metab. 13 (3 Pt 2), 326-330.

Post, W., Goldschmidt-clermont, P. J., Wilhide, C. C., Heldman, A. W., Sussman, M. S., Ouyang, P., et al. (1999). Methylation of the Estrogen Receptor Gene Is Associated with Aging and Atherosclerosis in the Cardiovascular System. Cardiovasc. Res. 43 (4), 985-991. doi:10.1016/s0008-6363(99)00153-4

Promislow, D. (1992). Costs of Sexual Selection in Natural Populations of Mammals. Proc. R. Soc. Lond. B 247, 203-210. doi:10.1098/rspb.1992.0030

$\mathrm{Pu}$, X.-Y., Wang, X.-H., Gao, W.-C., Yang, Z.-H., Li, S.-L., Wang, H.-P., et al. (2008). Insulin-like Growth Factor-1 Restores Erectile Function in Aged Rats: Modulation the Integrity of Smooth Muscle and Nitric Oxide-Cyclic Guanosine Monophosphate Signaling Activity. J. Sex. Med. 5 (6), 1345-1354. doi:10.1111/ j.1743-6109.2008.00817.x

Rajagopalan, S., and Long, E. O. (2012). Cellular Senescence Induced by CD158d Reprograms Natural Killer Cells to Promote Vascular Remodeling. Proc. Natl. Acad. Sci. 109, 20596-20601. doi:10.1073/pnas.1208248109
Ramsey, M. M., Weiner, J. L., Moore, T. P., Carter, C. S., and Sonntag, W. E. (2004). Growth Hormone Treatment Attenuates Age-Related Changes in Hippocampal Short-Term Plasticity and Spatial Learning. Neuroscience 129 (1), 119-127. doi:10.1016/j.neuroscience.2004.08.001

Rauscher, F. M., Goldschmidt-clermont, P. J., Davis, B. H., Wang, T., Gregg, D., Ramaswami, P., et al. (2003). Aging, Progenitor Cell Exhaustion, and Atherosclerosis. Circulation 108, 457-463. doi:10.1161/ 01.CIR.0000082924.75945.48

Reddy, A. K., Li, Y.-H., Pham, T. T., Ochoa, L. N., Treviño, M. T., Hartley, C. J., et al. (2003). Measurement of Aortic Input Impedance in Mice: Effects of Age on Aortic Stiffness. Am. J. Physiology-Heart Circulatory Physiol. 285 (4), H1464-H1470. doi:10.1152/ajpheart.00004.2003

Redheuil, A., Yu, W.-C., Wu, C. O., Mousseaux, E., De Cesare, A., Yan, R., et al. (2010). Reduced Ascending Aortic Strain and Distensibility. Hypertension 55 (2), 319-326. doi:10.1161/HYPERTENSIONAHA.109.141275

Reed, A. L., Tanaka, A., Sorescu, D., Liu, H., Jeong, E.-M., Sturdy, M., et al. (2011). Diastolic Dysfunction Is Associated with Cardiac Fibrosis in the Senescence-Accelerated Mouse. Am. J. Physiology-Heart Circulatory Physiol. 301 (3), H824-H831. doi:10.1152/ajpheart.00407.2010

Rivard, A., Fabre, J.-E., Silver, M., Chen, D., Murohara, T., Kearney, M., et al. (1999). Age-dependent Impairment of Angiogenesis. Circulation 99 (1), 111-120. doi:10.1161/01.cir.99.1.111

Roberson, R. S., Kussick, S. J., Vallieres, E., Chen, S.-Y. J., and Wu, D. Y. (2005). Escape from Therapy-Induced Accelerated Cellular Senescence in P53-Null Lung Cancer Cells and in Human Lung Cancers. Cancer Res. 65 (7), 2795-2803. doi:10.1158/0008-5472.CAN-04-1270

Robert, L., and Fulop, T. (2014). Aging of Cell Communication: Loss of Receptor Function. Interdiscip. Top. Gerontol. 39, 142-162. doi:10.1159/ 000358903

Robert, L. (1998). Mechanisms of Aging of the Extracellular Matrix: Role of the Elastin-Laminin Receptor. Gerontology 44, 307-317. doi:10.1159/000022034

Rodier, F., Coppé, J.-P., Patil, C. K., Hoeijmakers, W. A. M., Muñoz, D. P., Raza, S. R., et al. (2009). Persistent DNA Damage Signalling Triggers SenescenceAssociated Inflammatory Cytokine Secretion. Nat. Cel Biol 11 (8), 973-979. doi:10.1038/ncb1909

Rodríguez, S. A., Grochová, D., McKenna, T., Borate, B., Trivedi, N. S., Erdos, M. R., et al. (2016). Global Genome Splicing Analysis Reveals an Increased Number of Alternatively Spliced Genes with Aging. Aging Cell 15 (2), 267-278. doi:10.1111/acel.12433

Rodríguez-Mañas, L., El-assar, M., Vallejo, S., López-Dóriga, P., Solís, J., Petidier, R., et al. (2009). Endothelial Dysfunction in Aged Humans Is Related with Oxidative Stress and Vascular Inflammation. Aging Cell 8 (3), 226-238. doi:10.1111/j.1474-9726.2009.00466.x

Rosner, W., Auchus, R. J., Azziz, R., Sluss, P. M., and Raff, H. (2007). Utility, Limitations, and Pitfalls in Measuring Testosterone: An Endocrine Society Position Statement. J. Clin. Endocrinol. Metab. 92 (2), 405-413. doi:10.1210/ jc.2006-1864

Rudman, D., Feller, A. G., Nagraj, H. S., Gergans, G. A., Lalitha, P. Y., Goldberg, A. F., et al. (1990). Effects of Human Growth Hormone in Men over 60 Years Old. N. Engl. J. Med. 323 (1), 1-6. doi:10.1056/NEJM199007053230101

Rudolph, K. L., Chang, S., Lee, H.-W., Blasco, M., Gottlieb, G. J., Greider, C., et al. (1999). Longevity, Stress Response, and Cancer in Aging Telomerase-Deficient Mice. Cell 96, 701-712. doi:10.1016/s0092-8674(00)80580-2

Russell, E. S. (2007). "'Lifespan and Aging Patterns" in the Biology of the Laboratory Mouse," in Adapted for Web by: Mouse Genome Informatics (MGI). Editor E. L. Green (Maine: The Jackson Laboratory Bar Harbor).

Ruzankina, Y., Pinzon-Guzman, C., Asare, A., Ong, T., Pontano, L., Cotsarelis, G., et al. (2007). Deletion of the Developmentally Essential Gene ATR in Adult Mice Leads to Age-Related Phenotypes and Stem Cell Loss. Cell Stem Cell 1 (1), 113-126. doi:10.1016/j.stem.2007.03.002

Salton, C. J., Chuang, M. L., O’Donnell, C. J., Kupka, M. J., Larson, M. G., Kissinger, K. V., et al. (2002). Gender Differences and normal Left Ventricular Anatomy in an Adult Population Free of Hypertension. J. Am. Coll. Cardiol. 39 (6), 1055-1060. doi:10.1016/s0735-1097(02)01712-6

Salvatori, R., Hayashida, C. Y., Aguiar-Oliveira, M. H., Phillips, J. A., 3rd., Souza, A. H. O., Gondo, R. G., et al. (1999). Familial Dwarfism Due to a Novel Mutation of the Growth Hormone-Releasing Hormone Receptor Gene1. J. Clin. Endocrinol. Metab. 84 (3), 917-923. doi:10.1210/jcem.84.3.5599 
Scuteri, A., Morrell, C. H., Orrù, M., Strait, J. B., Tarasov, K. V., Ferreli, L. A. P., et al. (2014). Longitudinal Perspective on the Conundrum of central Arterial Stiffness, Blood Pressure, and Aging. Hypertension 64 (6), 1219-1227. doi:10.1161/HYPERTENSIONAHA.114.04127

Sengupta, P. (2013). The Laboratory Rat: Relating its Age with Human's. Int. J. Prev. Med. 4 (6), 624-630.

Shiels, P. G., Mcglynn, L. M., Macintyre, A., Johnson, P. C. D., Batty, G. D., Burns, H., et al. (2011). Accelerated Telomere Attrition Is Associated with Relative Household Income, Diet and Inflammation in the pSoBid Cohort. PLoS One 6 (7), e22521. doi:10.1371/journal.pone.0022521

Shipley, R., and Mullerdelp, J. (2005). Aging Decreases Vasoconstrictor Responses of Coronary Resistance Arterioles through Endothelium-dependent Mechanisms. Cardiovasc. Res. 66 (2), 374-383. doi:10.1016/j.cardiores.2004.11.005

Siegel, J. J., and Amon, A. (2012). New Insights into the Troubles of Aneuploidy. Annu. Rev. Cel Dev. Biol. 28, 189-214. doi:10.1146/annurev-cellbio-101011155807

Simpkins, J. W., Huang, H. H., Advis, J. P., and Meites, J. (1979). Changes in Hypothalamic NE and DA Turnover Resulting from Steroid-Induced LH and Prolactin Surges in Ovariectomized Rats1. Biol. Reprod. 20 (3), 625-632. doi:10.1095/biolreprod20.3.625

Skaug, E.-A., Aspenes, S. T., Oldervoll, L., Mørkedal, B., Vatten, L., Wisløff, U., et al. (2013). Age and Gender Differences of Endothelial Function in 4739 Healthy Adults: the HUNT3 Fitness Study. Eur. J. Prev. Cardiolog 20 (4), 531-540. doi:10.1177/2047487312444234

Slobodnyuk, K., Radic, N., Ivanova, S., Llado, A., Trempolec, N., Zorzano, A., et al. (2019). Autophagy-induced Senescence Is Regulated by P38a Signaling. Cell Death Dis 10, 376. doi:10.1038/s41419-019-1607-0

Smith, J. C., Evans, L. M., Wilkinson, I., Goodfellow, J., Cockcroft, J. R., Scanlon, M. F., et al. (2002). Effects of GH Replacement on Endothelial Function and LargeArtery Stiffness in GH-Deficient Adults: a Randomized, Double-Blind, PlaceboControlled Study. Clin. Endocrinol. (Oxf). 56 (4), 493-501. doi:10.1046/ j.1365-2265.2002.01514.x

Sonntag, W. E., Lynch, C. D., Cooney, P. T., and Hutchins, P. M. (1997). Decreases in Cerebral Microvasculature with Age Are Associated with the Decline in Growth Hormone and Insulin-like Growth Factor $1^{*}$. Endocrinology 138 (8), 3515-3520. doi:10.1210/endo.138.8.5330

Sonntag, W. E., Ramsey, M., and Carter, C. S. (2005). Growth Hormone and Insulin-like Growth Factor-1 (IGF-1) and Their Influence on Cognitive Aging. Ageing Res. Rev. 4 (2), 195-212. doi:10.1016/j.arr.2005.02.001

Storer, J. B. (1966). Longevity and Gross Pathology at Death in 22 Inbred Mouse Strains. J. Gerontol. 21 (3), 404-409. doi:10.1093/geronj/21.3.404

Storer, M., Mas, A., Robert-moreno, A., Pecoraro, M., Ortells, M. C., Di Giacomo, V., et al. (2013). Senescence Is a Developmental Mechanism that Contributes to Embryonic Growth and Patterning. Cell 155 (5), 1119-1130. Epub 2013 Nov 14. PMID: 24238961. doi:10.1016/j.cell.2013.10.041

Straub, R. H., Konecna, L., Hrach, S., Rothe, G., Kreutz, M., Schölmerich, J., et al. (1998). Serum Dehydroepiandrosterone (DHEA) and DHEA Sulfate Are Negatively Correlated with Serum Interleukin-6 (IL-6), and DHEA Inhibits IL-6 Secretion from Mononuclear Cells in Manin Vitro: Possible Link between Endocrinosenescence and Immunosenescence. J. Clin. Endocrinol. Metab. 83 (6), 2012-2017. doi:10.1210/jcem.83.6.4876

Suh, Y., Atzmon, G., Cho, M.-O., Hwang, D., Liu, B., Leahy, D. J., et al. (2008). Functionally Significant Insulin-like Growth Factor I Receptor Mutations in Centenarians. Proc. Natl. Acad. Sci. 105 (9), 3438-3442. doi:10.1073/ pnas. 0705467105

Taddei, S., Virdis, A., Ghiadoni, L., Mattei, P., Sudano, I., Bernini, G., et al. (1996). Menopause Is Associated with Endothelial Dysfunction in Women. Hypertension 28 (4), 576-582. doi:10.1161/01.hyp.28.4.576

Taddei, S., Virdis, A., Ghiadoni, L., Salvetti, G., Bernini, G., Magagna, A., et al. (2001). Age-related Reduction of NO Availability and Oxidative Stress in Humans. Hypertension 38 (2), 274-279. doi:10.1161/01.hyp.38.2.274

Taddei, S., Virdis, A., Mattei, P., Ghiadoni, L., Fasolo, C. B., Sudano, I., et al. (1997). Hypertension Causes Premature Aging of Endothelial Function in Humans. Hypertension 29 (3), 736-743. doi:10.1161/01.hyp.29.3.736

Taddei, S., Virdis, A., Mattei, P., Ghiadoni, L., Gennari, A., Fasolo, C. B., et al. (1995). Aging and Endothelial Function in Normotensive Subjects and Patients with Essential Hypertension. Circulation 91 (7), 1981-1987. doi:10.1161/ 01.cir.91.7.1981
Takeda, T., Hosokawa, M., Takeshita, S., Irino, M., Higuchi, K., Matsushita, T., et al. (1981). A New Murine Model of Accelerated Senescence. Mech. Ageing Dev. 17, 183-194. doi:10.1016/0047-6374(81)90084-1

Takeda, T. (1999). Senescence-accelerated Mouse (SAM): a Biogerontological Resource in Aging Research. Neurobiol. Aging 20 (2), 105-110. PMID: 10537019. doi:10.1016/s0197-4580(99)00008-1

Tang, X., Luo, Y.-x., Chen, H.-z., and Liu, D.-p. (2014). Mitochondria, Endothelial Cell Function, and Vascular Diseases. Front. Physiol. 5, 175. doi:10.3389/ fphys.2014.00175

Teede, H. (2007). Sex Hormones and the Cardiovascular System: Effects on Arterial Function in Women. Clin. Exp. Pharmacol. Physiol. 34 (7), 672-676. doi:10.1111/j.1440-1681.2007.04658.x

Thum, T., Hoeber, S., Froese, S., Klink, I., Stichtenoth, D. O., Galuppo, P., et al. (2007). Age-Dependent Impairment of Endothelial Progenitor Cells Is Corrected by Growth Hormone Mediated Increase of Insulin-like Growth Factor-1. Circ. Res. 100 (3), 434-443. doi:10.1161/01.RES.0000257912.78915.af

Tian, M., Shinkura, R., Shinkura, N., and Alt, F. W. (2004). Growth Retardation, Early Death, and DNA Repair Defects in Mice Deficient for the Nucleotide Excision Repair Enzyme XPF. Mol. Cel Biol 24, 1200-1205. doi:10.1128/ mcb.24.3.1200-1205.2004

Torella, D., Rota, M., Nurzynska, D., Musso, E., Monsen, A., Shiraishi, I., et al. (2004). Cardiac Stem Cell and Myocyte Aging, Heart Failure, and Insulin-like Growth Factor-1 Overexpression. Circ. Res. 94 (4), 514-524. doi:10.1161/ 01.RES.0000117306.10142.50

Trifunovic, A., Wredenberg, A., Falkenberg, M., Spelbrink, J. N., Rovio, A. T., Bruder, C. E., et al. (2004). Premature Ageing in Mice Expressing Defective Mitochondrial DNA Polymerase. Nature 429 (6990), 417-423. doi:10.1038/ nature 02517

Ungvari, Z., and Csiszar, A. (2012). The Emerging Role of IGF-1 Deficiency in Cardiovascular Aging: Recent Advances. Journals Gerontol. Ser. A: Biol. Sci. Med. Sci. 67A (6), 599-610. doi:10.1093/gerona/gls072

Ungvari, Z., Orosz, Z., Labinskyy, N., Rivera, A., Xiangmin, Z., Smith, K., et al. (2007). Increased Mitochondrial H2O2 Production Promotes Endothelial NF$\mathrm{Kb}$ Activation in Aged Rat Arteries. Am. J. Physiology-Heart Circulatory Physiol. 293, H37-H47. doi:10.1152/ajpheart.01346.2006

Ungvari, Z., Sonntag, W. E., and Csiszar, A. (2010). Mitochondria and Aging in the Vascular System. J. Mol. Med. 88 (10), 1021-1027. doi:10.1007/s00109-0100667-5

United Nations (2019). Department of Economic and Social Affairs, Population Division. World Population Ageing 2019: Highlights (ST/ESA/SER.A/430). New York: UN DESA Department.

van den Beld, A. W., Bots, M. L., Janssen, J. A., Pols, H. A., Lamberts, S. W., and Grobbee, D. E. (2003). Endogenous Hormones and Carotid Atherosclerosis in Elderly Men. Am. J. Epidemiol. 157, 25-31. doi:10.1093/aje/kwf160

Van Der Harst, P., Van Der Steege, G., De Boer, R. A., Voors, A. A., Hall, A. S., Mulder, M. J., et al. (2007). Telomere Length of Circulating Leukocytes Is Decreased in Patients with Chronic Heart Failure. J. Am. Coll. Cardiol. 49 (13), 1459-1464. doi:10.1016/j.jacc.2007.01.027

Van Der Loo, B., Labugger, R., Skepper, J. N., Bachschmid, M., Kilo, J., Powell, J. M., et al. (2000). Enhanced Peroxynitrite Formation Is Associated with Vascular Aging. J. Exp. Med. 192 (12), 1731-1744. doi:10.1084/jem.192.12.1731

van der Lugt, N. M., Domen, J., Linders, K., van Roon, M., Robanus-Maandag, E., te Riele, H., et al. (1994). Posterior Transformation, Neurological Abnormalities, and Severe Hematopoietic Defects in Mice with a Targeted Deletion of the Bmi1 Proto-Oncogene. Genes Dev. 8, 757-769. doi:10.1101/gad.8.7.757

van der Pluijm, I., Garinis, G. A., Brandt, R. M. C., Gorgels, T. G. M. F., Wijnhoven, S. W., Diderich, K. E. M., et al. (2007). Impaired Genome Maintenance Suppresses the Growth Hormone-insulin-like Growth Factor 1 Axis in Mice with Cockayne Syndrome. Plos Biol. 5, e2. doi:10.1371/journal.pbio.0050002

Van Deursen, J. M. (2014). The Role of Senescent Cells in Ageing. Nature 509, 439-446. doi:10.1038/nature13193

Verlohren, S., Dubrovska, G., Tsang, S.-Y., Essin, K., Luft, F. C., Huang, Y., et al. (2004). Visceral Periadventitial Adipose Tissue Regulates Arterial Tone of Mesenteric Arteries. Hypertension 44, 271-276. doi:10.1161/01.hyp.0000140058.28994.ec

Virani, S. S., Alonso, A., Benjamin, E. J., Bittencourt, M. S., Callaway, C. W., Carson, A. P., et al. (2020). Heart Disease and Stroke Statistics-2020 Update: A Report from the American Heart Association. Circulation 141 (9), e139-e596. doi:10.1161/CIR.0000000000000757 
Virdis, A., Ghiadoni, L., Pinto, S., Lombardo, M., Petraglia, F., Gennazzani, A., et al. (2000). Mechanisms Responsible for Endothelial Dysfunction Associated with Acute Estrogen Deprivation in Normotensive Women. Circulation 101, 2258-2263. doi:10.1161/01.cir.101.19.2258

Virmani, R., Avolio, A. P., Mergner, W. J., Robinowitz, M., Herderick, E. E., Cornhill, J. F., et al. (1991). Effect of Aging on Aortic Morphology in Populations with High and Low Prevalence of Hypertension and Atherosclerosis. Comparison between Occidental and Chinese Communities. Am. J. Pathol. 139 (5), 1119-1129.

Vlachopoulos, C., Aznaouridis, K., and Stefanadis, C. (2010). Prediction of Cardiovascular Events and All-Cause Mortality with Arterial Stiffness. J. Am. Coll. Cardiol. 55 (13), 1318-1327. PMID: 20338492. doi:10.1016/j.jacc.2009.10.061

Walston, J., Fedarko, N., Yang, H., Leng, S., Beamer, B., Espinoza, S., et al. (2008). The Physical and Biological Characterization of a Frail Mouse Model. J. Gerontol. A. Biol. Sci. Med. Sci. 63 (4), 391-398. doi:10.1093/gerona/63.4.391

Wang, L., Yang, L., Debidda, M., Witte, D., and Zheng, Y. (2007). Cdc42 GTPaseActivating Protein Deficiency Promotes Genomic Instability and Premature Aging-like Phenotypes. Proc. Natl. Acad. Sci. 104 (4), 1248-1253. doi:10.1073/ pnas.0609149104

Wang, M., Khazan, B., and G. Lakatta, E. (2010). Central Arterial Aging and Angiotensin II Signaling. Chyr 6 (4), 266-281. doi:10.2174/ 157340210793611668

Warner, H. R., and Sierra, F. (2003). Models of Accelerated Ageing Can Be Informative about the Molecular Mechanisms of Ageing And/or AgeRelated Pathology. Mech. Ageing Dev. 124 (5), 581-587. doi:10.1016/s00476374(03)00008-3

Weeda, G., Donker, I., de Wit, J., Morreau, H., Janssens, R., Vissers, C. J., et al. (1997). Disruption of Mouse ERCC1 Results in a Novel Repair Syndrome with Growth Failure, Nuclear Abnormalities and Senescence. Curr. Biol. 7, 427-439. doi:10.1016/s0960-9822(06)00190-4

Wei, J., Xu, H., Davies, J. L., and Hemmings, G. P. (1992). Increase of Plasma IL-6 Concentration with Age in Healthy Subjects. Life Sci. 51 (25), 1953-1956. doi:10.1016/0024-3205(92)90112-3

Wijshake, T., Malureanu, L. A., Baker, D. J., Jeganathan, K. B., van de Sluis, B., and van Deursen, J. M. (2012). Reduced Life- and Healthspan in Mice Carrying a Mono-Allelic BubR1 MVA Mutation. Plos Genet. 8 (12), e1003138. doi:10.1371/journal.pgen.1003138

Wong, C. M., Yao, X., Au, C. L., Tsang, S. Y., Fung, K. P., Laher, I., et al. (2006). Raloxifene Prevents Endothelial Dysfunction in Aging Ovariectomized Female Rats. Vasc. Pharmacol. 44 (5), 290-298. Epub 2006 Mar 15. PMID: 16542882. doi:10.1016/j.vph.2005.12.005

World Health Organization (2015). Department of Economic and Social Affairs, Population Division. World Population Ageing 2015 (ST/ESA/SER.A/390). New York: WHO Department of Economic and Social Affairs. Available at: http://
www.un.org/en/development/desa/population/publications/pdf/ageing/WPA2 015_Report.pdf (Accessed June 18, 2017).

Wullschleger, S., Loewith, R., and Hall, M. N. (2006). TOR Signaling in Growth and Metabolism. Cell 124 (3), 471-484. doi:10.1016/j.cell.2006.01.016

Xiao, R. P., Tomhave, E. D., Wang, D. J., Ji, X., Boluyt, M. O., Cheng, H., et al. (1998). Age-associated Reductions in Cardiac $\beta 1$ - and $\beta 2$-adrenergic Responses without Changes in Inhibitory G Proteins or Receptor Kinases. J. Clin. Invest. 101 (6), 1273-1282. doi:10.1172/JCI1335

Xu, Z., Duc, K. D., Holcman, D., and Teixeira, M. T. (2013). The Length of the Shortest Telomere as the Major Determinant of the Onset of Replicative Senescence. Genetics 194, 847-857. doi:10.1534/genetics.113.152322

Yuan, M., Wen-xia, Z., Jun-ping, C., and Yong-xiang, Z. (2005). Age-related Changes in the Oestrous Cycle and Reproductive Hormones in Senescence-Accelerated Mouse. Reprod. Fertil. Dev. 17 (5), 507. doi:10.1071/rd04099

Yuan, R., Tsaih, S.-W., Petkova, S. B., De Evsikova, C. M., Xing, S., Marion, M. A., et al. (2009). Aging in Inbred Strains of Mice: Study Design and Interim Report on Median Lifespans and Circulating IGF1 Levels. Aging Cell 8 (3), 277-287. doi:10.1111/j.1474-9726.2009.00478.x

Zhavoronkov, A. (2020). The Inherent Challenges of Classifying Senescence. Science 368 (6491), 1-595. doi:10.1126/science.aba0833

Zhou, X., and Frohlich, E. D. (2003). Ageing, Hypertension and the Kidney: New Data on an Old Problem. Nephrol. Dial. Transplant. 18 (8), 1442-1445. doi:10.1093/ndt/gfg193

Zieman, S. J., Gerstenblith, G., Lakatta, E. G., Rosas, G. O., Vandegaer, K., Ricker, K. M., et al. (2001). Upregulation of the Nitric Oxide-cGMP Pathway in Aged Myocardium. Circ. Res. 88 (1), 97-102. doi:10.1161/01.res.88.1.97

Conflict of Interest: The authors declare that the research was conducted in the absence of any commercial or financial relationships that could be construed as a potential conflict of interest.

Publisher's Note: All claims expressed in this article are solely those of the authors and do not necessarily represent those of their affiliated organizations, or those of the publisher, the editors and the reviewers. Any product that may be evaluated in this article, or claim that may be made by its manufacturer, is not guaranteed or endorsed by the publisher.

Copyright (C) 2021 Barros, Costa, Akamine and Tostes. This is an open-access article distributed under the terms of the Creative Commons Attribution License (CC BY). The use, distribution or reproduction in other forums is permitted, provided the original author(s) and the copyright owner(s) are credited and that the original publication in this journal is cited, in accordance with accepted academic practice. No use, distribution or reproduction is permitted which does not comply with these terms. 


\section{GLOSSARY}

ACE Angiotensin converting enzyme

Ang II Angiotensin-II

AT1 Ang II type 1 receptor

BH4 Tetrahydrobiopterin

BLSA The Baltimore Longitudinal Study on Aging

COX-1 Cyclooxygenase-1

COX-2 Cyclooxygenase-2

COX Cyclooxygenase

$\mathrm{Cu} / \mathrm{Zn}$-SOD Cytosolic superoxide dismutase

CVD Cardiovascular diseases

EDV Endothelium-dependent vasodilation

ER Estrogen receptor

ERE Estrogen-responsive element

FHS The Framingham cohort study

FSH Follicle-stimulating hormone

GH Growth Hormone

HIF-1a Hypoxia-inducible factor 1-alpha

hTERT Telomerase reverse transcriptase

ICD International Classification of Disease Code

IGF-1 Insulin-like Growth Factor 1

IL-1 Interleukin-1
IL-18 Interleukin-18

IL-6 Interleukin-6

$\mathrm{KCl}$ Potassium chloride

L-NAME L-NG-Nitroarginine Methyl Ester

LH Luteinizing hormone

Mn-SOD Mitochondrial superoxide dismutase

NAD(P)H Nicotinamide adenine dinucleotide phosphate

NF-кB Nuclear factor kappa B

NIA National Institute of Aging

NO Nitric oxide

$\mathbf{O}_{2}{ }^{-} \bullet$ Superoxide anion

OVX Ovariectomy

PVAT Perivascular adipose tissue

RNS Reactive nitrogen species

ROS Reactive oxygen species

SAMP Senescence-accelerated mouse prone

SAMR Senescence-accelerated resistant mouse prone

SASP Senescence-associated secretory phenotype

SHBG Sex hormone-binding globulin

SOD Superoxide dismutase

TNF- $\boldsymbol{\alpha}$ Tumor necrosis factor- $\alpha$

VEGF Vascular endothelial growth factor

VSMC Vascular smooth muscle cell 